\title{
Locating the festival, positioning the feast: natural and calendar festivals in medieval Slovenia
}

Article

Accepted Version

Čaval, S. (2018) Locating the festival, positioning the feast: natural and calendar festivals in medieval Slovenia. World Archaeology, 50 (2). pp. 300-322. ISSN 0043-8243 doi: https://doi.org/10.1080/00438243.2018.1538814 Available at https://centaur.reading.ac.uk/82779/

It is advisable to refer to the publisher's version if you intend to cite from the work. See Guidance on citing.

To link to this article DOI: http://dx.doi.org/10.1080/00438243.2018.1538814

Publisher: Taylor \& Francis

All outputs in CentAUR are protected by Intellectual Property Rights law, including copyright law. Copyright and IPR is retained by the creators or other copyright holders. Terms and conditions for use of this material are defined in the End User Agreement.

$\underline{\text { www.reading.ac.uk/centaur }}$ 
Central Archive at the University of Reading

Reading's research outputs online 
Journal acronym: RWAR

Author(s): $\quad$ Saša Čaval

Article title: Natural and calendar festivals in medieval Slovenia

Article no: $\quad 1538814$

Enclosures: $\quad$ 1) Query sheet

2) Article proofs

Dear Author,

1. Please check these proofs carefully. It is the responsibility of the corresponding author to check these and approve or amend them. A second proof is not normally provided. Taylor \& Francis cannot be held responsible for uncorrected errors, even if introduced during the production process. Once your corrections have been added to the article, it will be considered ready for publication.

Please limit changes at this stage to the correction of errors. You should not make trivial changes, improve prose style, add new material, or delete existing material at this stage. You may be charged if your corrections are excessive (we would not expect corrections to exceed 30 changes).

For detailed guidance on how to check your proofs, please paste this address into a new browser window: http://journalauthors.tandf.co.uk/production/checkingproofs.asp

Your PDF proof file has been enabled so that you can comment on the proof directly using Adobe Acrobat. If you wish to do this, please save the file to your hard disk first. For further information on marking corrections using Acrobat, please paste this address into a new browser window: http://journalauthors.tandf.co.uk/production/acrobat.asp

2. Please review the table of contributors below and confirm that the first and last names are structured correctly and that the authors are listed in the correct order of contribution. This check is to ensure that your name will appear correctly online and when the article is indexed.

\begin{tabular}{|l|l|l|l|l|}
\hline Sequence & Prefix & Given name(s) & Surname & Suffix \\
\hline 1 & & Saša & Čaval & \\
\hline
\end{tabular}


Queries are marked in the margins of the proofs, and you can also click the hyperlinks below.

Content changes made during copy-editing are shown as tracked changes. Inserted text is in red font and revisions have a red indicator $\lambda$. Changes can also be viewed using the list comments function. To correct the proofs, you should insert or delete text following the instructions below, but do not add comments to the existing tracked changes.

\section{AUTHOR QUERIES}

\section{General points:}

1. Permissions: You have warranted that you have secured the necessary written permission from the appropriate copyright owner for the reproduction of any text, illustration, or other material in your article. Please see http://journalauthors.tandf.co.uk/permissions/usingThirdPartyMaterial.asp.

2. Third-party content: If there is third-party content in your article, please check that the rightsholder details for re-use are shown correctly.

3. Affiliation: The corresponding author is responsible for ensuring that address and email details are correct for all the co-authors. Affiliations given in the article should be the affiliation at the time the research was conducted. Please see http://journalauthors.tandf.co.uk/preparation/writing.asp.

4. Funding: Was your research for this article funded by a funding agency? If so, please insert 'This work was supported by <insert the name of the funding agency in full>', followed by the grant number in square brackets '[grant number xxxx]'.

5. Supplemental data and underlying research materials: Do you wish to include the location of the underlying research materials (e.g. data, samples or models) for your article? If so, please insert this sentence before the reference section: 'The underlying research materials for this article can be accessed at < full link> / description of location [author to complete]' If your article includes supplemental data, the link will also be provided in this paragraph. See $<$ http://journalauthors.tandf.co.uk/preparation/multimedia.asp > for further explanation of supplemental data and underlying research materials.

6. The CrossRef database (www.crossref.org/) has been used to validate the references. Changes resulting from mismatches are tracked in red font.

AQ1 The ORCID for Saša Čaval provided has been taken from Manuscript and verified against public API, and was found to be invalid. Please supply correct ORCID.

AQ2 Please check whether Affiliations set correctly.

AQ3 The year for "Xiaojian, 2011" has been changed to 2010 to match the entry in the references list. Please provide revisions if this is incorrect.

AQ4 What is DEM? Please give acronyms in full at first appearance.

AQ5 Please check all the captions for the rendering of non-standard characters. "?" appears in the place of many, esp. in the captions for Figures 2, 6 and 10

AQ6 The reference "Lane 1996" is cited in the text but is not listed in the references list. Please either delete in-text citation or provide full reference details following journal style [http://www.tandf.co.uk/journals/authors/style/reference/tf_ChicagoAD.pdf] 
AQ7 The reference "Mills 2000" is cited in the text but is not listed in the references list. Please either delete in-text citation or provide full reference details following journal style [http://www.tandf.co.uk/journals/authors/style/reference/tf_ChicagoAD.pdf]

AQ8 Please provide missing Figure 12 caption.

AQ9 The year for "Ruggles, 2015" has been changed to 2005 to match the entry in the references list. Please provide revisions if this is incorrect.

AQ10 The CrossRef database (www.crossref.org/) has been used to validate the references. Mismatches between the original manuscript and CrossRef are tracked in red font. Please provide a revision if the change is incorrect. Do not comment on correct changes.

AQ11 Please provide complete details in reference "Caval et al., forthcoming".

AQ12 Please provide missing editor name or institutional editor name for the "de Blaauw, 2014" references list entry.

AQ13 Please provide missing Publisher name for the "de Blaauw, 2016" references list entry.

AQ14 The reference "Lawrence, 2015" is listed in the references list but is not cited in the text. Please either cite the reference or remove it from the references list.

AQ15 Please provide missing Publisher location for the "McCormick, 2011" references list entry.

AQ16 The reference "McCormick, 2011" is listed in the references list but is not cited in the text. Please either cite the reference or remove it from the references list.

AQ17 The reference "NASA, 0000" is listed in the references list but is not cited in the text. Please either cite the reference or remove it from the references list.

AQ18 The reference "Smolik, 2000b" is listed in the references list but is not cited in the text. Please either cite the reference or remove it from the references list.

AQ19 Please provide missing Publisher location for the "Taylor, 1993" references list entry. 


\section{How to make corrections to your proofs using Adobe Acrobat/Reader}

Taylor \& Francis offers you a choice of options to help you make corrections to your proofs. Your PDF proof file has been enabled so that you can mark up the proof directly using Adobe Acrobat/ Reader. This is the simplest and best way for you to ensure that your corrections will be incorporated. If you wish to do this, please follow these instructions:

1. Save the file to your hard disk.

2. Check which version of Adobe Acrobat/Reader you have on your computer. You can do this by clicking on the "Help" tab, and then "About".

If Adobe Reader is not installed, you can get the latest version free from http://get.adobe.com/ reader/.

3. If you have Adobe Acrobat/Reader 10 or a later version, click on the "Comment" link at the righthand side to view the Comments pane.

4. You can then select any text and mark it up for deletion or replacement, or insert new text as needed. Please note that these will clearly be displayed in the Comments pane and secondary annotation is not needed to draw attention to your corrections. If you need to include new sections of text, it is also possible to add a comment to the proofs. To do this, use the Sticky Note tool in the task bar. Please also see our FAQs here:

http://journalauthors.tandf.co.uk/production/index.asp.

5. Make sure that you save the file when you close the document before uploading it to CATS using the "Upload File" button on the online correction form. If you have more than one file, please zip them together and then upload the zip file.

If you prefer, you can make your corrections using the CATS online correction form.

\section{Troubleshooting}

Acrobat help: http://helpx.adobe.com/acrobat.html

Reader help: http://helpx.adobe.com/reader.html

Please note that full user guides for earlier versions of these programs are available from the Adobe Help pages by clicking on the link "Previous versions" under the "Help and tutorials" heading from the relevant link above. Commenting functionality is available from Adobe Reader 8.0 onwards and from Adobe Acrobat 7.0 onwards.

Firefox users: Firefox's inbuilt PDF Viewer is set to the default; please see the following for instructions on how to use this and download the PDF to your hard drive: http://support.mozilla.org/en-US/kb/view-pdf-files-firefox-without-downloading-them\#w_using-apdf-reader-plugin 
ARTICLE

\title{
Natural and calendar festivals in medieval Slovenia
}

\author{
Saša Čaval
}

Department of Anthropology, Stanford University, Stanford, CA, U.S.A.; Department of Archaeology, The School of Archaeology, Geography and Environmental Science, University of Reading, Reading, U.K.

\section{ABSTRACT}

The astronomical cycles and occurrences of the Sun, Moon, planets and certain star constellations were well known to prehistoric, Roman and medieval communities. Archaeoastronomy studies how ancient societies incorporated this knowledge into various aspects of past cultures. The discipline draws on modern astronomy, geodesy, physics, statistics, anthropology, ethnology and archaeology to study and interpret a wide range of source materials, from structural alignments to art, artefacts and inscriptions. This paper presents archaeoastronomical research on the orientation of Romanesque churches across the territory of modern-day Slovenia, focusing on an array of medieval festivals associated with the solstices and equinoxes. It demonstrates a profound connection between these festivals and the alignment of churches.

\section{KEYWORDS}

Cultural astronomy; archaeoastronomy; church orientation; medieval period; festivals; Slovenia

\section{Introduction}

Archaeological materials relating to religion and ritual are fragmentary (Fogelin 2007); however, modern developments in the discipline have equipped us to infer the intangible from the material culture. Religion in past cultures was expressed through ritual practice. These practices could incorporate unique locations,and specific moments in time (Renfrew 1985; Insoll 2011). To understand these two aspects of ritual, we have to understand which strategies were used to define a meaningful location, and how specific time markers were determined as important and subsequently incorporated into the event. Archaeoastronomy provides a methodology that teases out the significance of both temporal and spatial facets of rituals and celebrations.

This paper explores the largely neglected connections between church alignments and festivals in the Middle Ages, drawing on the rich corpus of data from the territory of modern Slovenia, part of the historical Holy Roman Empire. The research on Romanesque church orientations presented here highlights the importance of the specific juxtaposition of location and time - a combination producing a moment of religious significance - following the widespread acceptance of Christianity in the south-eastern Alpine region.

\section{Medieval astronomy, 'sacred direction' and the Church}

Much inherited knowledge of astronomy was lost towards the end of the Roman period, only to be rediscovered in the Arab world at the end of the first millennia (McCluskey 1998, ix). The medieval

CONTACT Saša Čaval scaval@stanford.edu @ Department of Anthropology, Stanford University, 450 Serra Mall, Main Quad, Bldg. 50, Stanford, CA 94305, U.S.A.

(C) 2018 Informa UK Limited, trading as Taylor \& Francis Group 
astronomical traditions that survived through the early Middle Ages included:(1) the observations of the rising and setting sun to determine cyclically and ritually critical dates; (2) monastic timekeeping, which was concerned with identifying and marking ritual times over the course of a day and night by observations of the movement of the stars to specify correct times for prayer; and (3) the computus, a precise discipline built upon arithmetical formulae and devoted to the calculation of the date of Easter and other movable feasts of the liturgical year (McCluskey 1998, x-xiii; Goldstein 1972; Helms 2004; Eastwood 2007, 1, 96-103; Nothaft 2018, 2).

Astronomical traditions reflect, and contribute to, socio-cultural values. For instance, the significance of particular cardinal directions is designed by the specificities of a given culture and it becomes all the more powerful and articulate if and when it is linked to a supernatural principle, belief or religion. The positions taken in prayer, and the layout of sacred structures, are not happenstance; they have been determined according to the predominant religious outlook (Landsberger 1957, 181). The Old Testament mentions 'four corners of the earth' and a four-part division of the mythical landscapes beyond Earth (Gordon 1971). One of the four is east. But what is 'east'? In strictly geographical terminology, it is a cardinal direction with an azimuth of $90^{\circ}$. However, more generally it is comprehended as one-quarter of the horizon: a quarter or $90^{\circ}$ of a plane within which we interact with people, objects and space. East has been a sacred direction for many cultures and religions, its adoration seemingly associated with the rising of the Sun (Thijm 1858; Landsberger 1957; Gordon 1971; Podossinov 1991, Xiaojian 2010 ; Taylor 1993).

Churches are generally aligned towards the east. However, there is more to the term orientation and especially to the practice of structure alignment itself. Today orientation is understood as a positioning in relation to surroundings or circumstances. The word originates from the Latin word orient, which means 'east' or 'rising', Architectural orientation is an ancient tradition, treated in detail in Vitruvius' De architectura (BC 30-15), one of the oldest and most influential works on architecture. The author discussed private, secular and sacred building orientation, in its horizontal (generally E-W direction, mainly due to the impression of sunrise and sunset) and vertical dimensions (the penetration of light into the building, relying on the movement of the Sun during the day) (Rowland and Howe 2001; Incerti 2013; cf. Heilbron [2001]). While early Christian works, such as Didascalia Apostolorum, and theological scholars, including Tertullian of Carthage, Origen and Clement of Alexandria, wrote about the orientation of churches and the direction of prayers towards the east, the first Ecumenical Council in Nicaea in AD 325 determined both as a decree (Kocik 2003): churches had to be aligned towards the east. Nevertheless, many early churches in Rome, Jerusalem, Antioch and elsewhere, while having eastward alignment, had their altar on the western side of the building. Therefore, during the religious ceremony, unlike the believers, the priest was facing the east, towards the source of the light (de Blaauw 2012, 2014, 326). Due to the range of possible eastern orientations, the proper direction for church alignments and prayer remained a much-debated topic within many medieval treatises. Among many authors, St Augustine (AD 354-430) thought that regardless of the fact that God is omnipresent, people should pray turned to the east (Vogel et al. 1962, 182; McCluskey 2004, 203). St Paulinus of Nola (AD 354-431) believed that the apse should be to the east of a church (Vogel et al. 1962, 187). St Columban ( $A D$ 543-615), in his monastic rules Regula coenobialis, mentioned the single permissible reason for monks not turning east when crossing themselves, which speaks of the importance of the east in liturgical tasks (McCluskey 2004, 203). In his prominent Etymologiae, St Isidore, Archbishop of Seville $\left(A D_{\mathcal{L}} \mathrm{Ca}_{\lambda}\right.$ 560-636, discussed the eastward direction at prayer and of shrines from prehistory and the time of pagan temples to well into Christianity. He used the word temple as a common name for sacred buildings, including churches, and advocated for them to be built 
with their altar to the east, the entrance to the west, and the left and right sides of the building aligned to the north and south respectively (Thijm 1858, 11; McCluskey 2004, 201). Following Isidore's evocation of the past, Walafrid Strabo (AD 808-849), reflected that Christian churches should imitate the orientation of Solomon's temple, i.e. toward the equinoctial sunrise (McCluskey 2004, 204).

The twelfth- and thirteenth-century authors shifted from 'the east' to more specific 'the equinoctial east', with Jean Beleth, Sicard of Cremona and the bishop Guillaume Durand explicitly declining the solstitial orientation (Vogel et al. 1962, 206). The medieval French astronomer William of Saint Cloude added a scientific and practical dimension with his Kalendarium Regine, where he described how to determine true east on any day of the year, since 'churches should be oriented with this line [of the eastern east], because only the right east indicates our Lord.'As the right or the true east $\left(A=90^{\circ}\right.$, vide infra) lies in the same direction irrespective of geographical location, and since the churches with their orientation 'point to Jesus', should have such alignment (McCluskey 2004, 205).

In current scholarship on archaeoastronomy, the astronomical orientation of sacred structures is the more studied theme, although sacred spaces also interface with local physical conditions and have not been based on purely religious lines (cf. Ratzinger [2014, 77]; Gangui et al. [2016]). The impact of landscape is clear in the distribution of early churches in Slovenia, with most positioned on highly visible hilltop locations, which often directed their orientation (cf. Čaval and Šprajc [2011]). Several hypotheses about churches with astronomically motivated alignments include, among others, the orientation towards the true or cardinal east; towards the sunrise on the church's patron-saint festival; towards the sunrise of both solstices $\lambda$ and keeping the alignment of previous sacred structures (McCluskey 2015, 1707). The latter hypothesis, of churches being built on the base of sacred pagan structures, retaining a pre-Christian orientation, stems from two prominent sources. First, the Western Roman Emperor, Honorius, issued an edict in AD 408 forbidding the destruction of pagan temples, instead requiring that they be converted into churches (Boyd 1905, 15-32; Coleman 1914, 219-41; Barnish 2001: Bradley 2002, 112-24). Second, in the well-known AD 601 correspondence between St Gregory the Great and St Augustine, Archbishop of Canterbury, the pope recommended that 'the temples of the idols' should not be destroyed but converted into Christian churches. He also advocated overlying pagan festivals with a Christian 'solemnity', either in the form of a 'day of the dedication or the nativities of the holy martyrs' (Bede 1907, 103).

The astronomical orientation of churches was thought to become largely irrelevant either by the end of the Romanesque period (Firneis and Köberl 1988, 431), or by the seventeenth century (Thijm 1858, 13). However, a recent study of churches from the fifteenth to the nineteenth centuries on Lanzarote, Canary Islands, proved this idea inaccurate (Gangui et al. 2016).

Today the symbolism of the east remains powerful and authoritative. Indeed, the original and still practised Coptic rite keeps in its liturgy a warning before a prayer: 'Turn to the east!' (Kocik 2003, 26). Likewise, prior to becoming pope, Benedict XVI stressed the importance of performing present-day liturgical activities in the direction of east (Ratzinger 1986, 139-41). The meaning of church orientations maintained in the Romanesque architecture of Slovenia is the subject to which I now turn. 


\section{Materials and methods}

The Romanesque style was the first distinctive pan-European artistic form to dominate western and central Europe. It spanned the tenth to the end of the thirteenth centuries, depending on the region. Romanesque architecture is characterized by a large and heavy outlook, thick walls, a few small windows, semi-circular arches, large towers, and ornamental arcading, as well as regular, symmetrical plans (Fernie 2014). Most Slovenian Romanesque churches are predominantly single-nave, with either a semi-circular apse, i.e. the Mediterranean type, or a square presbytery, i.e. the northern type. The circular apse followed Late Antique architectural design, which existed in the region from the Early Christian period and became the primary church type in the wider area due to the Aquileian influence. The square presbytery arrived in the Adriatic region from the north; it originated in Nordic wooden architecture and was brought to central Europe by Irish and Scottish missionaries (Zadnikar 1982, 59; cf. Andrén [2013]). Representative for the area of the Salzburg archdiocese, the square presbytery was in use until the Gothic style period in the fourteenth century (Zadnikar 1982, 2001; Höfler 2016).

In total, 174 churches form the corpus of data upon which the present research is based, accounting for some $80 \%$ of all Romanesque churches in Slovenia, and as such representing a significant and robust dataset. Ideally, all period-relevant churches would have been included, but this was not possible due to the fact that in some churches the key Romanesque features, such as the nave, or the phase itself, had not been preserved. Most churches have been architecturally embellished and/or extended over time, with a narthex, transept, side chapels or a bell tower added, along with the chancel and the altar area re-built.

Archaeoastronomy borrows a large portion of methodology from modern astronomy and physics. The analyses of the azimuths (A) (Figure 1) and declinations ( $\delta$ ) have been instrumental for the present case (Figure 2, Figure 3). The study focused on both eastern and western horizons. The main axes of churches were defined by measuring both longitudinal walls and averaging the results. The fieldwork and computational methods for the alignment determination have been published elsewhere (Schaefer 1993; Aveni 2001; Ruggles 1999; Čaval, Zakšek, and Šprajc forthcoming); therefore, methodological particulars are summarized here:

(1) All measurements were taken with a theodolite to avoid global magnetic declination and local magnetic deviations (due to iron rods in the walls, local anomalies influencing the magnetic compass bearing, and so on) (Aveni 2001; Magli 2016, 31-5).

(2) The astronomic reference for the measurements was the Sun.

(3) Altitudes of the two horizons were measured in the direction of azimuths of the churches' outside longitudinal walls, respectively. When the horizon was obscured, an algorithm using DEM was employed (Čaval, Zakšek, and Šprajc forthcoming).

(4) For statistical calculations, the margin of error had to be estimated for A, horizon altitudes and rough datation of churches respectively and considered when interpreting the declinations.

Once these data were collected and processed, they needed to be related to celestial objects. The two brightest celestial bodies in our solar system, when viewed from Earth, are the Sun and the Moon. Their symbolic representations are widely acknowledged and discussed elsewhere (for example, but not limited to, Hutton [2001]; Heilbron [2001]; Penprase [2017]). The Sun in particula々 emerged as the most obvious inspiration for the 


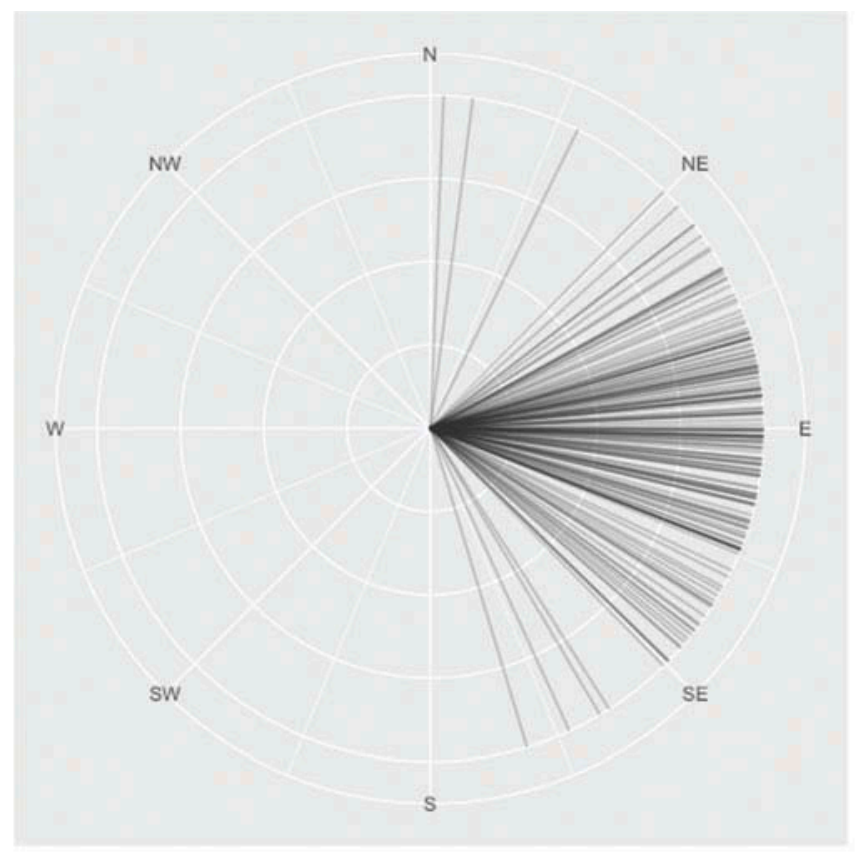

azimuth

(a)

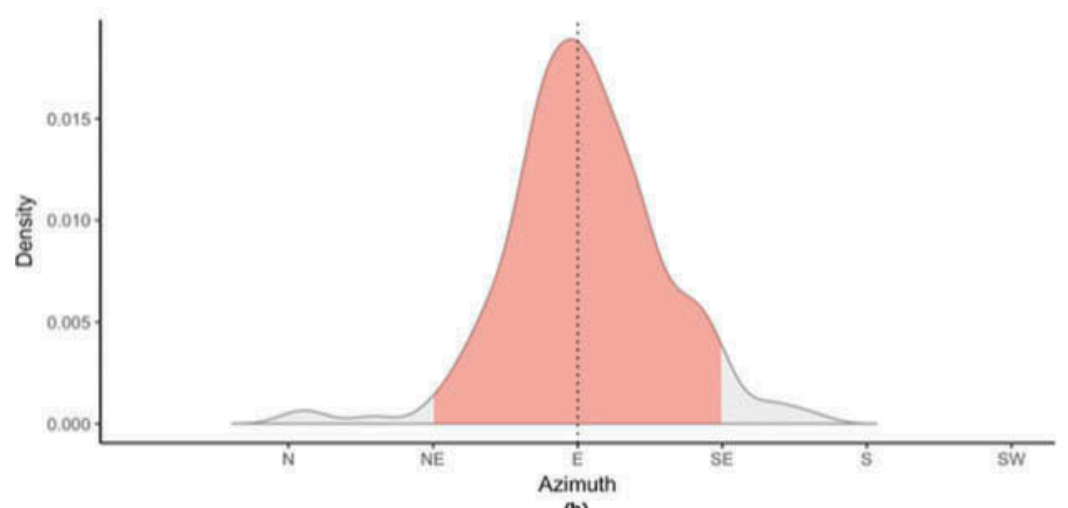

(b)

Figure 1. $(a, b)$ The azimuth diagrams of the Romanesque churches in Slovenia show that $97.4 \%$ of churches have eastern azimuths $(A)$, with the highest density a few degrees off the true east $(E)$, towards the north $(N)$. A is the angle measured in the horizontal plane clockwise, starting from the $\mathrm{N}$, having values from $0^{\circ}$ to $360^{\circ}$. The values between $45^{\circ}(\mathrm{NE})$ and $135^{\circ}(\mathrm{SE})$ are defined as east; however, only $\mathrm{A}=90^{\circ}$ corresponds to the true $\mathrm{E}$. The $1 \mathrm{~b}$ diagram was produced using Gaussian kernel density estimate (Graphics by Claudia Engel, Stanford University, U.S.A.).

orientations. The calendar is another crucial factor that has to be acknowledged when studying astronomical alignments. During the period and geographical region under study, the solar-based Julian calendar was in use (vide infra). Therefore, the data were converted into Julian dates. 


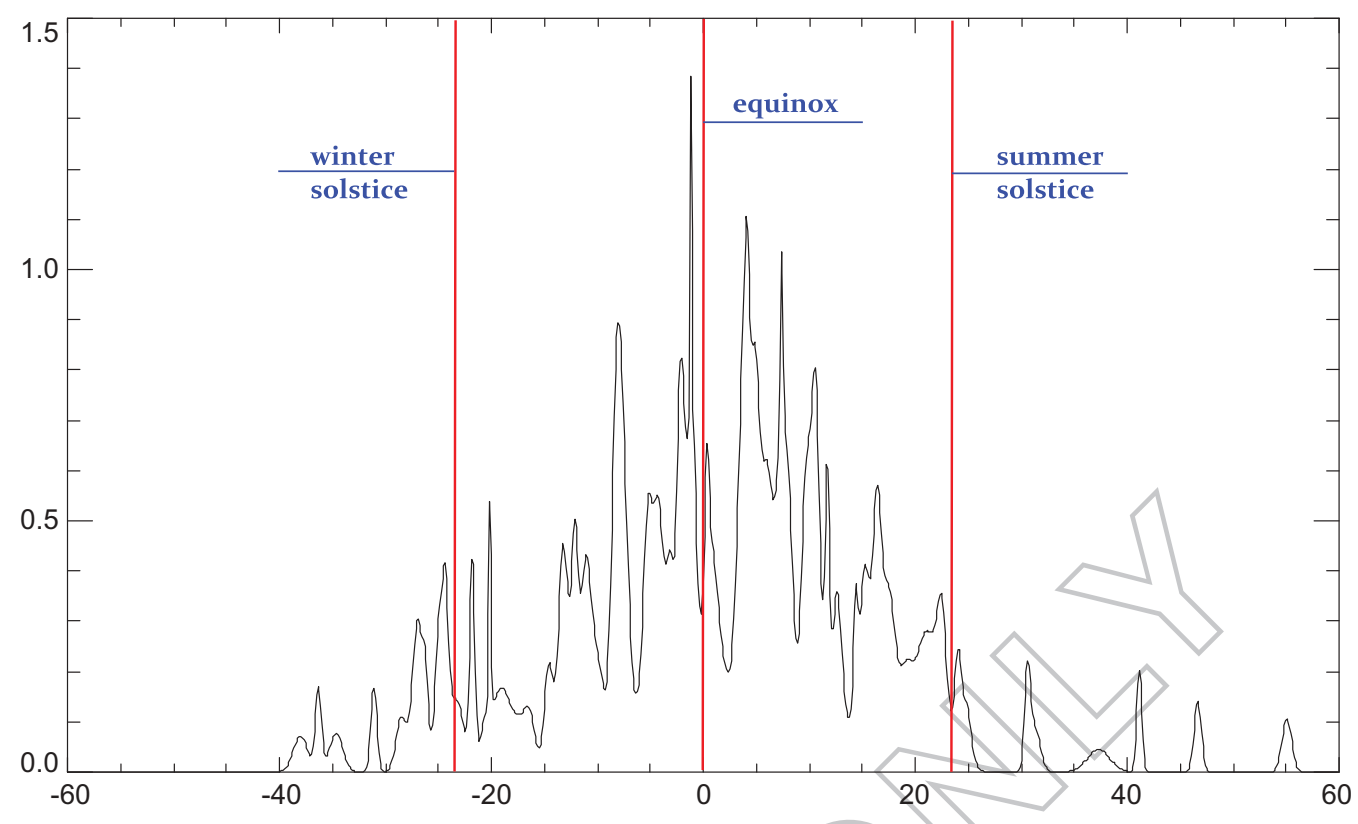

Figure 2. The cumulative histogram of the declinations (?) on the eastern horizon. ? is the angle between the plane of the celestial equator (Earth's equator projected onto the celestial sphere) and the position of a given celestial object on a celestial meridian, having values from $0^{\circ}$ at the celestial equator to $+90^{\circ}$ and $-90^{\circ}$. ? greater than $90^{\circ}$ do not occur, as both poles are the most northern and southern points of the celestial sphere; hence NP $?=+90^{\circ}$ and SP $?=-90^{\circ}$.

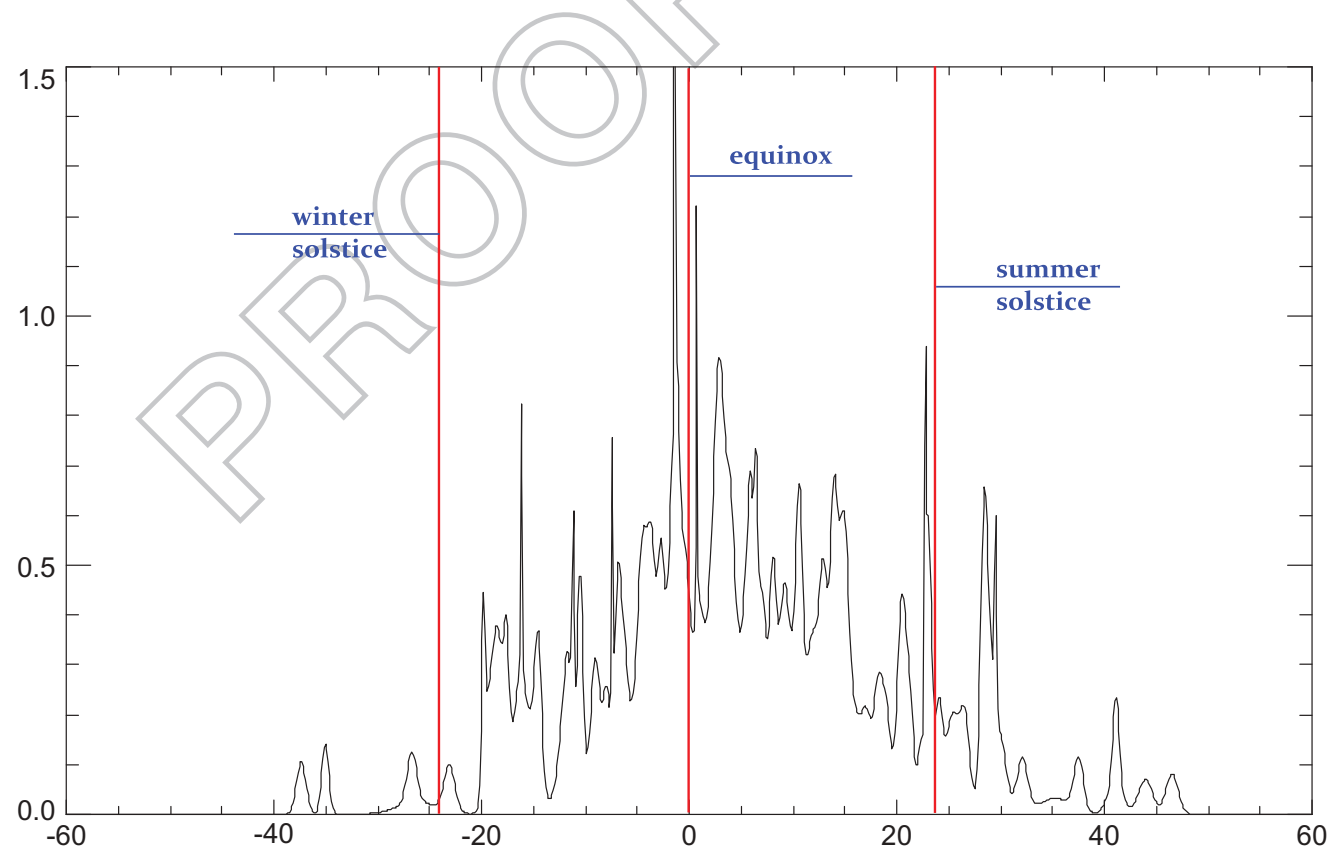

Figure 3. The cumulative histogram of the declinations (?) on the western horizon (Algorithm and graphics by Krištof Oštir, ZRC SAZU, Ljubljana, Slovenia). 


\section{Results}

Results were based on azimuths (A), declinations $(\delta)$ and calendar dates (the Julian and Gregorian).

\section{Azimuths}

Out of 174 churches studied, the vast majority (97\%) had their longitudinal axes in an east-west direction, which corroborates medieval written sources. These azimuths are not distributed evenly but are arranged into distinctive groups, which is the first indicator of their astronomical conditionality (Figure 1).

\section{Declinations}

While the examination of azimuths shows the church alignments regarding cardinal direction, the analysis of declinations sheds light on relevant celestial factors. Today, the $\delta$ of the Sun ranges between $+23^{\circ} 26^{\prime} 24^{\prime \prime}$ and $-23^{\circ} 26^{\prime} 24^{\prime \prime}$. However, in medieval times, due to the angle between the ecliptic and the equator gradually decreasing, the extreme $\delta$ were $\pm 23^{\circ} 54^{\prime}$ (Aveni $2001,103)$. The distribution of $\delta$ of churches' longitudinal axes demonstrates that most alignments can be linked to sunrises and sunsets on specific days of the year (Figure 2, Figure 3), which again corroborates the written sources. Effectively, these $\delta$ form groups around specific values. When the $\delta$ is converted into calendar dates, two dates are generated for each $\delta$, because the Sun on its annual path moves through each point - except the solstices - twice a year: from the winter solstice $\left(\delta=-23.5^{\circ} ; 21\right.$ December in 2016) to the vernal equinox $\left(\delta=0^{\circ} ; 20\right.$ March in 2017), towards the summer solstice $\left(\delta=+23.5^{\circ} ; 21\right.$ June in 2017), and back to the autumn equinox $\left(\delta=0^{\circ} ; 22\right.$ Septemben in 2017) and the winter solstice $\left(\delta=-23.5^{\circ} ; 22\right.$ December in 2017). Thus, we obtain two dates per cardinal direction per $\delta$, i.e. two dates for the eastern horizon and two for the western horizon, or, four dates for each church.

Understandably, not all four were intentionally targeted. The final interpretation has to be individually considered and involves the date that best fits with the church's contextual information; a date that conveys insight into the strategy used to determine the church's orientation at the time of construction. Thus, the alignment to a specific date had significance, either for the broader community or a particular benefactor of the church and had to be carefully determined. It may also have matched the alignment of a pre-Christian sacred structure on top of which the church was built.

\section{Calendar dates}

When converting $\delta$ into dates, we have to be aware of the correct calendar. The Julian calendar was the predominant calendar in Europe from BC 45, when Caesar reformed the old calendar to bring the festivities back into agreement with the seasons, in particular with the equinox (Mommsen 1859). In AD 1582, Pope Gregory XIII was compelled to do likewise. Thus, while the Gregorian calendar harmonizes with a solar year for more than 3030 years before the insertion of one day is required, in contrast, the Julian calendar accrued one day every 128 years. Hence, from BC 45 until AD 1582 almost 13 days of difference accumulated. Since the Gregorian calendar more accurately corresponds to the solar year, $\delta$ in this study were converted into proleptic Gregorian 


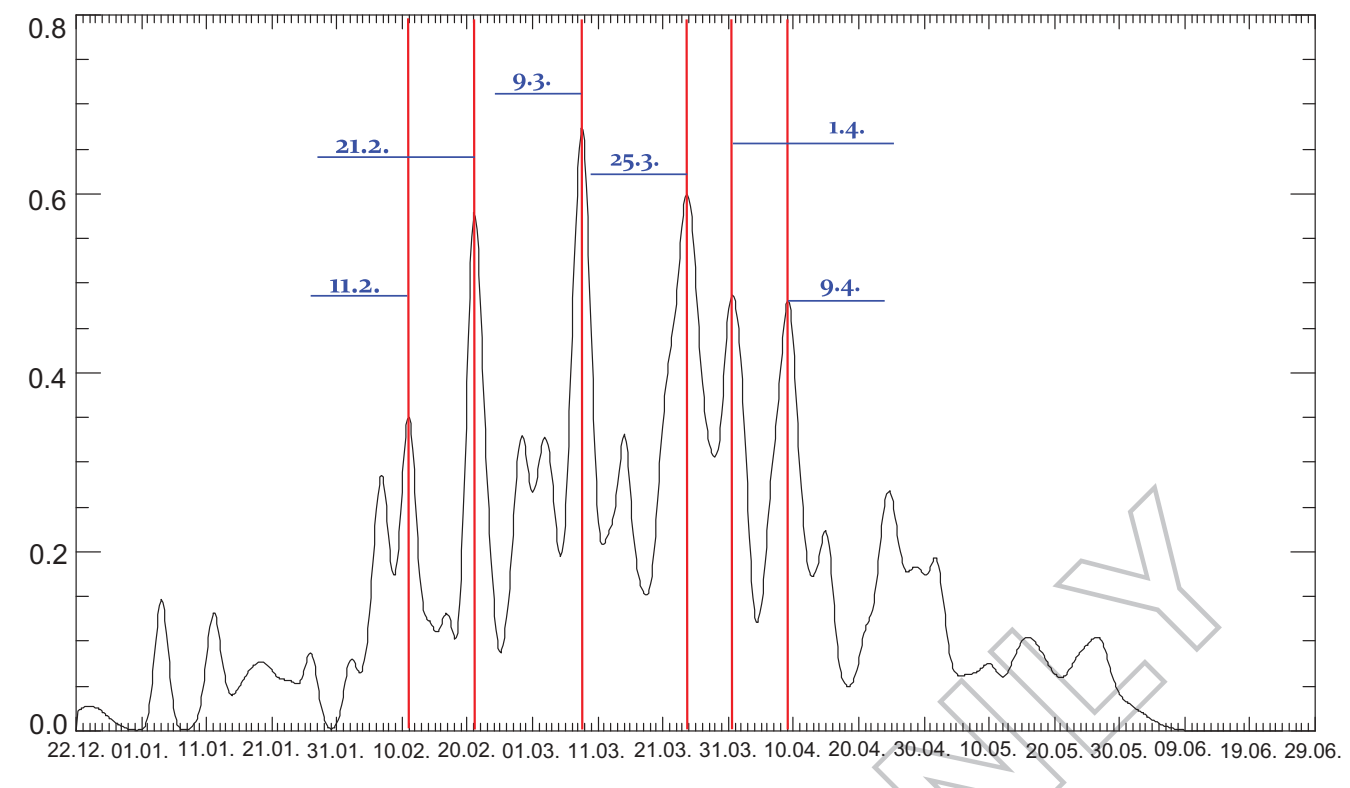

Figure 4. The cumulative histogram of Julian calendar dates in the first half of a year, corresponding to the declinations on the eastern horizon (Algorithm and graphics by Krištof Oštir, ZRC SAZU, Ljubljana, Slovenia).

calendar dates using conversion tables termed geocentric ephemeris, and, subsequently, according to the datation of each church, into Julian calendar dates. The latter are depicted in cumulative diagrams (Figure 4, Figure 5), where the peaks generally align with dates of particular significance in the medieval calendar.

\section{Natural and calendar festivals}

As a way to provide boundaries, the significant moments in a year were characterized as 'natural' and 'calendar' festivals, depending on the timekeeping method. Natural festivals are those that mark specific moments in the cycles of celestial bodies as recognized from Earth: for the Sun, this includes equinoxes and solstices; for the Moon, its phases; for the planets, the first and last appearances or other phenomena within their synodic periods; and so on. Prehistoric structural orientations register predominantly natural festivals. Those can be identified through observation of the movement of celestial bodies, usually regarding the horizon, i.e. their rising or setting. Natural festivals correspond to various calendar festivals. These are linked to specific calendars that display timekeeping records of particular cultures, and are shaped both by the society's cultural background and by the context of the historical moment. They correspond to what Victor Turner (1979) called the time of 'a calendrical ritual', For example, the festival of St_Peter's Chair on 22 February is a calendar festival, as it does not originate from an astronomically significant moment, but from a moment in the history of a specific culture/religion, thus having a special meaning only to the members of that culture/religion. Its historical context is captured in the fact that on this day the apostle Peter became the Bishop of Rome and therefore the leader of all Roman Catholic Christians. This day was a major festival in the early Christian and medieval periods (Balboni 1967), but lost its significance in modern times (Murphy 1960). An interesting example of a calendar festival is Easter, as it is based on a specific combination of natural festivals. 


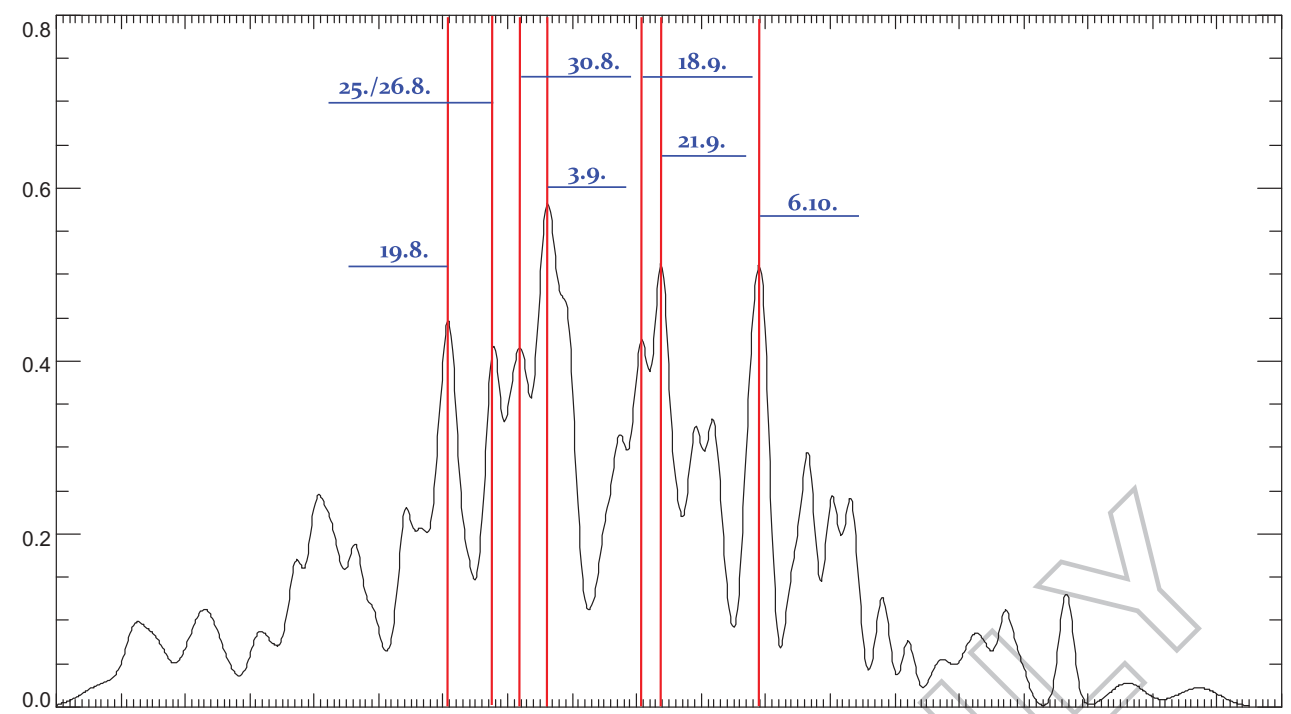

19.06. 29.06. 09.07. 19.07. 29.07. 08.08. 18.08.28.08. 07.09. 17.09. 27.09. 07.10. 17.10. 27.10. 06.11. 16.11. 26.11. 26.12. 16.12. 26.12.

Figure 5. The cumulative histogram of Julian calendar dates in the second half of a year, corresponding to the declinations on the eastern horizon (Algorithm and graphics by Krištof Oštir, ZRC SAZU, Ljubljana, Slovenia).

\section{Solstice}

The solstices are the two critical moments, the dividing points, in a solar year. The change in the length of a day had an immense impact on societies and cultures, and on conceptions of their spiritual and earthly world. In prehistoric societies, the orientations towards solstice sunrise and sunset were equally important (Ruggles 2005), while in medieval Christian communities the east, therefore the sunrise, was the most prominent (vide supra).

Determination of the solstice by observing the movement of the Sun on the horizon can be problematic, as the Sun at that time of a year moves very slowly. From ethnographic accounts of Native American societies, we learn that the movement of the Sun in respects to the horizon is observable with the naked eye only about a week before or after the solstice, when the Sun moves for about 10 arc minutes (10'). During these two weeks the Sun seems to be still (Zeilik 1985; McCluskey 1982; cf. Ruggles [1999]).

The early Christian calendar indisputably embraced traditional Roman dates for solstices and equinoxes, as noted by Pliny, AD 23-79: VIII Kal in January, April, July and October. Bede the Venerable defined the four cardinal points of the year following this designation and compared the turning points in Jesus's life with the Sun's annual phenomena. Not surprisingly, the four dates became major Christian festivals and particularly worthy of being recorded in the orientation of sacred architecture:

This is what some of the pagans say; and very many of the church's teachers [...], saying that our Lord was conceived and suffered on the 8th before the kalends of April [25th March], at the spring equinox, and that he was born at the winter solstice on the 8th before the kalends of January [25th December]. And again, that the Lord's blessed precursor and Baptist was conceived at the autumn equinox on the 8th before the kalends of October [24th September] and born at the summer solstice on the 8th before the kalends of July [24th June] ... [1]t was fitting that the Creator of eternal light should be conceived and born along with the increase of temporal light, and that the herald of penance, who must decrease, should be engendered and born at a time when the light is diminishing, (Nothaft 2011, 101) 
Bede was already aware of the incongruence between the Julian calendar and the mean tropical year, as he mentioned that:

[.... . as we have learned in connection with the calculation of Easter [...], it is in particular agreement that the spring equinox is on the 12th before the kalends of April [21 March], we think that the three other turning-points of the seasons ought to be observed a little before [the date] given in the popular treatises, (Nothaft 2011, 101)

Bede published the Reckoning of Time in AD 725, when the difference between both was four days (Tierney 1911; Newton 1972; Nothaft 2011), whereas the present study is focused on the period between the tenth and the end of the thirteenth century when the difference was six to seven days.

Acknowledging the uncertainties regarding the observations and the calendar and considering as solstitial orientations those with the $\delta= \pm 23.54^{\circ}$ and the margin of error $\pm 0.5^{\circ}$, there are 22 churches $(13 \%)$ oriented towards this natural feast: 16 churches towards summer solstice, five towards winter solstice and one towards both (Figure 6, Figure 7).

\section{Equinox}

Although measuring the exact day of the solstice is challenging, observation of a sunrise or sunset around equinoxes is straightforward. The position of the Sun on the horizon changes dramatically,

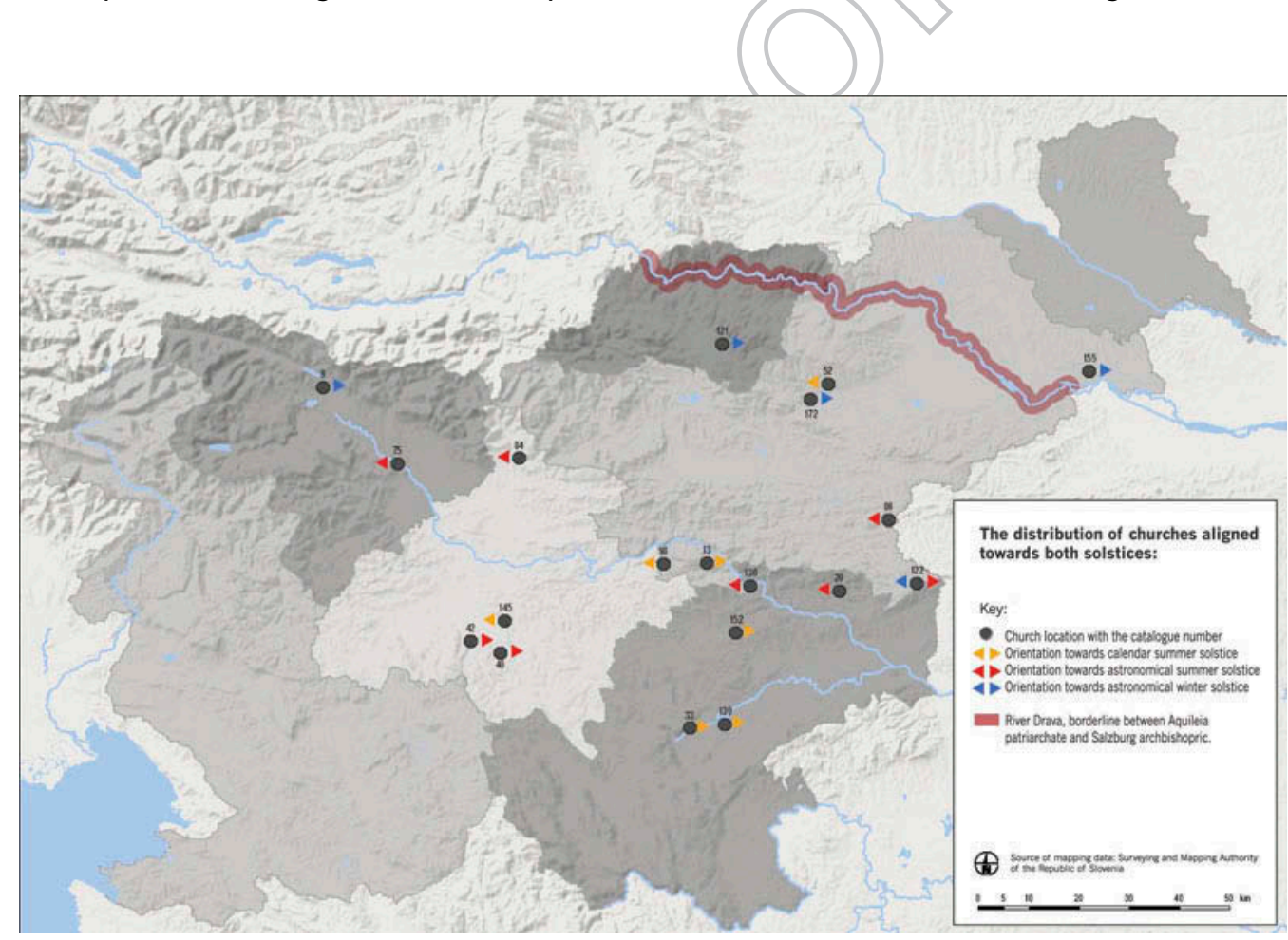

Figure 6. The distribution of churches aligned towards both solstices. The catalogue numbers with churches' locations: 8 - Breg pri Žirovnici, 13 - ?imerno, 20 - Dovško pri Senovem, 33 - Gorenja Straža, 36 - Gorenji Mokronog, 40 - Gradiš?e nad Želimljami, 42 - lška vas, 43 - Jakovica pri Planini, 49 - Kamnik, Mali grad, 52 - Koritno nad Oplotnico, 75 - Okroglo, 84 - Planina nad Kamnikom, 86 - Pod?etrtek, 98 - Rodež pod Kumom, 121 - Sv. Magdalena na Brdah, 122 - Svete gore, St. Goerge, Bistrica ob Sotli, 130 - Šentjur na Polju, 139 - Šmihel pri Novem mestu, 145 - Tlake, Šmarje Sap, 152 - Tržiš?e pri Mokronogu, 155 - Velika Nedelja, 172 - Zre?e (Graphics by Peter Pehani, ZRC SAZU, Ljubljana, Slovenia). 


\begin{tabular}{|c|c|c|c|c|c|c|c|}
\hline \multirow[b]{2}{*}{ ID } & \multirow[b]{2}{*}{ LOCATION } & \multirow[b]{2}{*}{ PATRON-SAINT } & \multirow[b]{2}{*}{$\begin{array}{l}\text { ARCHAEOL. } \\
\text { CONTINUITY }\end{array}$} & \multicolumn{2}{|c|}{ EAST } & \multicolumn{2}{|c|}{ WEST } \\
\hline & & & & DECLINATION & $\begin{array}{c}\text { MARGIN OF } \\
\text { ERROR }\end{array}$ & DECLINATION & $\begin{array}{c}\text { MARGIN OF } \\
\text { ERROR }\end{array}$ \\
\hline 13 & Čimerno & Trinity & $\mathrm{P}$ & 21,895 & 2,4333 & $-14,93538$ & 0,8333 \\
\hline 40 & Gradišče nad Želimljami & Primož,Felicijan & $P, R$ & 23,9787 & 0,1433 & $-19,51294$ & 0,1966 \\
\hline 42 & Iška vas & Michael & $P, R, M$ & 22,95463 & 1,3916 & $-0,32174$ & 0,4583 \\
\hline 121 & Sv. Magdalena na Brdah & Magdalene & 1 & $-23,09232$ & 0,7283 & 35,25471 & 2,3283 \\
\hline 122 & Svete gore nad Bistrico ob Sotli & George & $P, R, M$ & 24,76685 & 0,325 & $-23,14407$ & 0,4583 \\
\hline 152 & Tržišče pri Mokronogu & Mary & $P, R, M$ & 22,35523 & 2,3416 & $-2,51560$ & 0,9416 \\
\hline 172 & Zreče & Egidij & $P, R$ & $-23,55377$ & 0,6425 & 28,96325 & 0,6425 \\
\hline 20 & Dovško pri Senovem & Jacob & $\mathrm{P}$ & $-21,80205$ & 0,0866 & 23,97005 & 0,1533 \\
\hline 36 & Gorenji Mokronog & Peter & $P, R, M$ & $-14,31229$ & 0,5720 & 19,39444 & 8,4387 \\
\hline 43 & Jakovica pri Planini & Mary & $P, R$ & 41,09876 & 0,0991 & $-26,20356$ & 4,0325 \\
\hline 75 & Okroglo & Magdalene & 1 & $-21,89894$ & 0,0920 & 23,07482 & 0,0920 \\
\hline 84 & Planina nad Kamnikom & Primož,Felicijan & $\mathrm{P}$ & $-18,76538$ & 0,7833 & 24,62634 & 0,7166 \\
\hline 86 & Podčetrtek & Lawrence & $P, R$ & $-5,76497$ & 0,8225 & 24,94477 & 2,6225 \\
\hline 130 & Šentjur na Polju & George & $P, R$ & $-14,68489$ & 0,22 & 23,21071 & 0,1 \\
\hline 8 & Breg pri Žirovnici & Radegunda & $P, R, M$ & $-24,36857$ & 0.1154 & 28,34882 & 0.1820 \\
\hline 33 & Gorenja Straža & Thomas & $P, R$ & 22,49644 & 0,2029 & $-18,19072$ & 0,2562 \\
\hline 49 & Kamnik, Mali grad & Egidij & $\mathrm{M}$ & 20,9548 & 1,7912 & $-0,27333$ & 4,9912 \\
\hline 139 & Šmihel pri Novem mestu & Michael & $\mathrm{R}$ & 22,12265 & 0,4216 & $-19,88413$ & 0,035 \\
\hline 155 & Velika Nedelja & Trinity & $\mathrm{R}$ & $-24,47208$ & 0,3012 & 26,52872 & 0,3012 \\
\hline 52 & Koritno nad Oplotnico & Nicholas & $P, R$ & $-20,19345$ & 0,0216 & 22,85922 & 0,035 \\
\hline 98 & Rodež pod Kumom & Lenart & $P, R, M$ & $-11,09084$ & 6,5387 & 22,68079 & 0,0054 \\
\hline 145 & Tlake, Šmarje Sap & Cross & $\mathrm{R}$ & $-20,52295$ & 0,4858 & 22,35263 & 0,2058 \\
\hline
\end{tabular}

Figure 7. The data records for the churches oriented towards both solstices (Figure 6).

for three quarters of the Sun disc's diameter per day (Ruggles 1999). In the astronomical sense, equinox is the moment when the Sun, while circulating on its ecliptic path, intersects the celestial equator. This occurs twice a year, on the vernal and autumnal equinox: around 21 March and 23 September in Gregorian calendar (cf. Ruggles [1997]; cf. González-García and Belmonte [2006]). These are the only two moments in a solar year when the terminator - the line that parts the day from the night - is perpendicular to the Earth's equator, and both southern and northern hemispheres are equally illuminated. In the medieval period various calendar dates corresponded to 280 equinoxes (McCluskey 1998, 2007; González-García and Belmonte 2006) (Figure 8, Figure 9).

A similar situation can be found in the second half of the year (McCluskey 1998, 2007).

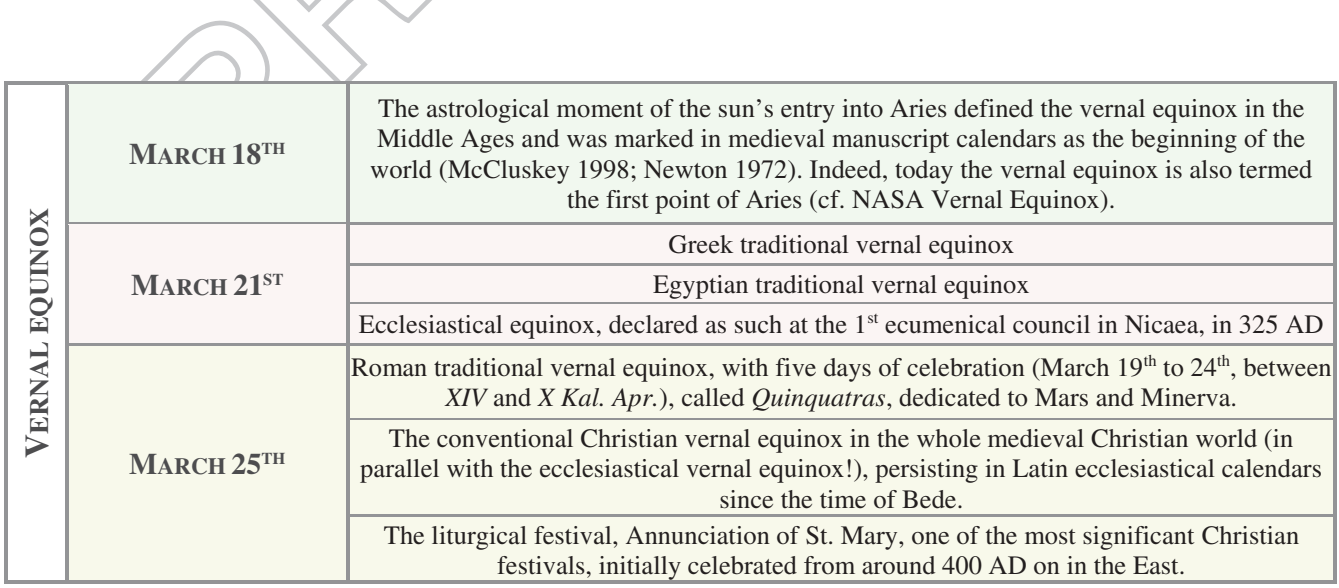

Figure 8. Calendar dates for vernal equinox. 


\begin{tabular}{|c|c|c|}
\hline \multirow{7}{*}{ 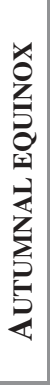 } & SEPTEMBER $17^{\mathrm{TH}}$ & $\begin{array}{l}\text { The Sun's entry into the sign of Scales, i.e. the autumnal equinox in the last } \\
\text { centuries of the } 1^{\text {st }} \text { millennium. }\end{array}$ \\
\hline & \multirow[b]{3}{*}{ SEPTEMBER $21^{\mathrm{ST}}$} & Greek traditional autumnal equinox \\
\hline & & The liturgical feast of the apostle and evangelist St. Matthew \\
\hline & & $\begin{array}{l}\text { The folk festival marking the beginning of winter in central European } \\
\text { countries, important as the medieval Slovenian territory was under the } \\
\text { Germanic ascendancy (Schauber and Schindler 1995). }\end{array}$ \\
\hline & \multirow{3}{*}{ SEPTEMBER $24^{\mathrm{TH}}$} & Roman traditional autumnal equinox \\
\hline & & The liturgical feast marking the Conception of St. John the Baptist \\
\hline & & $\begin{array}{l}\text { The liturgical feast of St. Rupert, the first bishop of Salzburg and preferred } \\
\text { patron saint of the archbishopric (Smolik 2000b; Höfler 2016) }\end{array}$ \\
\hline
\end{tabular}

Figure 9. Calendar dates for autumnal equinox.

Churches were interpreted as intentionally aligned towards the equinoxes when the $\delta=0^{\circ}$ or when the calendar dates corresponded to any of the aforementioned dates (Figure 2, Figure 3). The total number of those is 66 (37.9\%). If we take as equinoctial orientations only those with the $\delta$ within the span of $\pm 0.2^{\circ}$, we find 15 churches $(9 \%)$ oriented towards either of the astronomical equinoxes. This is a small number at first glance. However, these 15 churches also have a meaningful alignment on the other horizon, either eastern or western. Seven of those 15 churches cluster quite closely around the beginning of April/end of August and end of April/beginning of August, suggesting the orientations towards liturgical festivals of St Agape, Chionia, and Irene on 1 April/ (also on 3 April jor 5 April) (Smolik 2000a, 44; Schauber and Schindler 1995, 132), the Roman festival of Magna Mater on 4 April(with an exciting correlation to Cybele and her festivals in March, including 25 March; see Lane [1996]; Takács 1996; Šašel Kos 2010), St Augustine on 28 August_ or the Beheading of St John the Baptist on 29 August. The other eight churches record an unexpected range of festivals: one church, a solstice; two, the ecclesiastical equinox; another two, the Sun's entry into the astrological sign of Scales; and three churches, the Christian equinox of 25 March. To summarize, the latter eight churches on one horizon register the natural feast - the astronomical equinox $\left(\delta=0^{\circ} \pm 0.2^{\circ}\right)$ - while on the opposite horizon, they simultaneously record the calendar festival associated with a natural festival, mostly with the spring equinox (Figure 10). All of these churches were built on or in the immediate vicinity of prehistoric or Roman period archaeological sites (Figure 11), although the continuity of the exact sacred location has not been archaeologically confirmed.

\section{The vernacular calendar}

The aforementioned calendar festivals all refer to the related official calendars. The vernacular calendar provides another aspect of a community's timekeeping and festivities. The Slovenian medieval vernacular calendar was formed on the base of the period's prevailing economy, agriculture (Makarovič 1995, 15). It characterizes phases of agricultural processes and indicates agrarian turning points within a year. Through contacts with ecclesiastical and urban culture, the institutional temporality (Mills 2000), such as the liturgical seasons (cf. Hickman [1992, 13]), started to enter the vernacular calendar. By the late medieval period the church calendar merged with the rural populations' agrarian rhythm of life, and liturgical festivals became calendric estimates for agricultural tasks, fairs and festivities (Makarovič 1995, 45). 


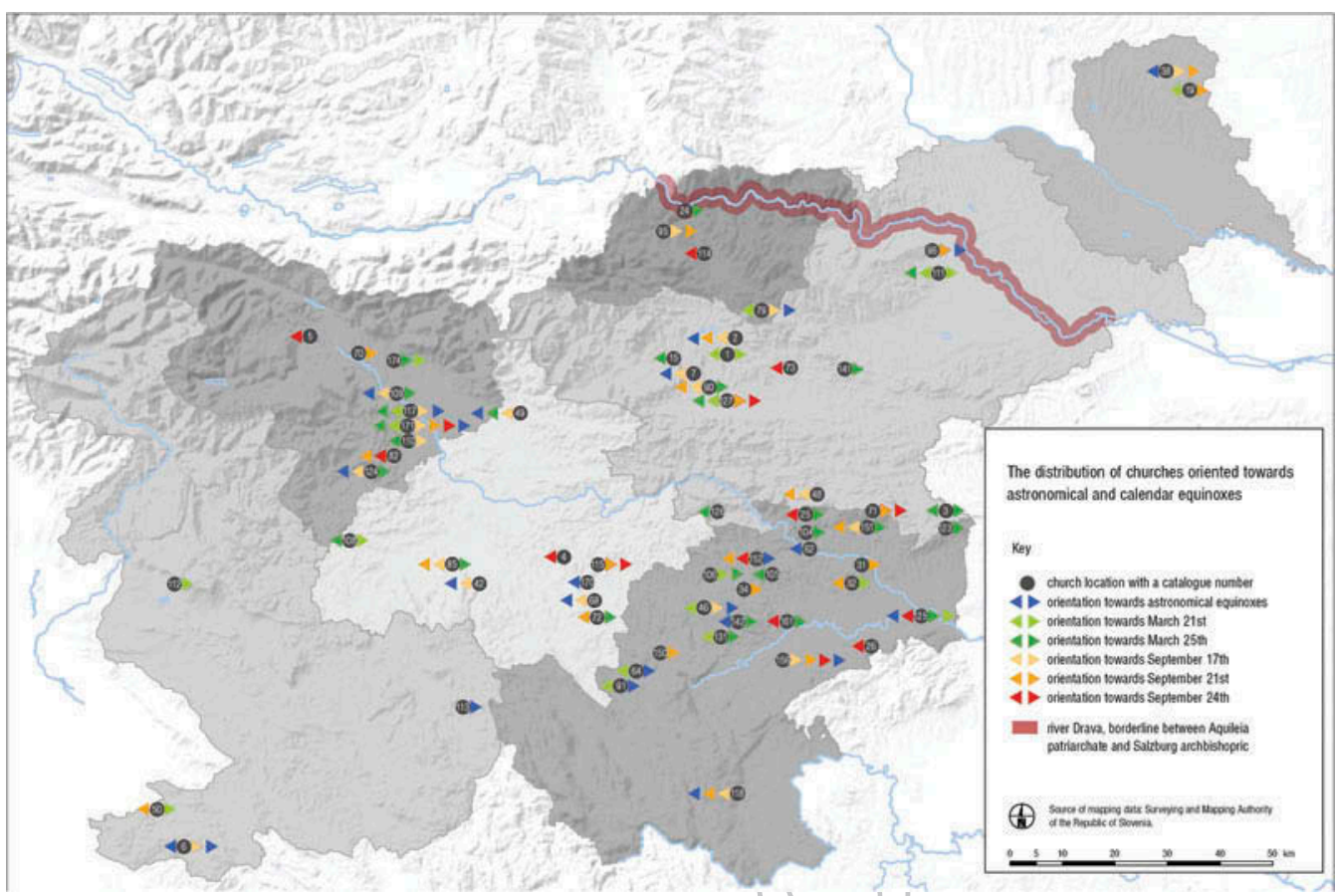

Figure 10. The distribution of churches with both calendar and astronomical orientations towards both vernal and autumnal equinoxes on both eastern and western horizons (Figure 8, Figure 9, Figure 11). The catalogue numbers of churches' locations: 1 - Arna?e, 2 - Bev?e, 3-Bistrica ob Sotli, 4 - Ble?ji vrh nad Višnjo goro, 5 Bled, otok, 6 - Boršt nad Koprom, 7 - Braslov?e, 15 - Dobrovlje nad Mozirjem, 19 - Domanjševci, 24 Dravograd, 25 - Drožanje, 26 - Frluga, 31 - Gora pri Krškem, 32 - Gorenja Lepa vas, 34 - Gorenje Laknice, 38 Gorenji Petrovci, 42 - lška vas, 46 - Jezero pri Trebnjem, 48 - Jurklošter, 49 - Kamnik, Mali grad, 50 - Koper, 62 - Log pri Sevnici, 64 - Lopata, 68 - Malo ?rnelo, 70 - Mošnje, 71 - Mrzla Planina pri Sevnici, 72 - Muljava, 73 Nova cerkev, 79 - Paški Kozjak, 82 - Pevno pri Škofji Loki, 85 - Planinca nad Jezerom, 90 - Polzela, 91 - Prevole, 95 - Ravne na Koroškem, 96 - Razvanje pri Mariboru, 104 - Sevnica, 105 - Slan?ji vrh, 106 - Slepšek, 108 Smre?je, 109 - Spodnja Besnica, 110 - Spodnje Bitnje, 111 - Spodnje Ho?e, 112 - Spodnje Vitovlje, 113 - Stari trg pri Ložu, 114 - Stari trg pri Slovenj gradcu, 115 - Sti?na, 117 - Stražǐ̌̌e, Kranj, 118 - Stražnji vrh, 123 - Svete Gore, 124 - Sv. Tomaž nad Škofjo Loko, 125 - Sv. Vid nad Brežicami, 126 - Svibno, 127 - Šempeter v Savinjski dolini, 131 - Šentjurij na Dolenjskem, 141 - Špitali?, 142 - Štatenberk, 150 - Treb?a vas, 151 - Trnovec nad Sevnico, 152 - Tržiš?e pri Mokronogu, 156 - Velike Brusnice, 161 - Vinji vrh pri Beli cerkvi, 170 - Zgornja Draga, 171 - Zgornje Bitnje, 174 - Žiganja vas (graphics by Peter Pehani, ZRC SAZU, Ljubljana, Slovenia).

Slovenian Protestant reformer Primož Trubar used the calendar assembled by Johannes Hildebrand, a magister in Tübingen, Germany, to document the first Slovenian calendar. Printed in 1557, it discerns the liturgical festivals observed as the beginnings of the agrarian seasons, and communicates the medieval tradition of associating saints' feasts with astronomical beginnings of the seasons (Trubar 1581/82, 1986; Makarovič 2006). The Trubar calendar gives the following feasts that served as an agrarian and astronomical division of a year into seasons (Figure 13). It is unknown how Trubar acquired the information he presented, However, if focusing specifically on the astronomical division it is clear that he noted the real-time movement of the Sun's cycle. Except Hildebrand did not track the actual astronomical situation for that year: the spring equinox in 1557 was on 10 March_(Smith 1996; Equinox and solstice). The dates for solstices and equinoxes, chronicled in the Trubar calendar, were misaligned with the existing celestial positions and marked 


\begin{tabular}{|c|c|c|c|c|c|c|c|c|c|}
\hline \multirow{2}{*}{ ID } & \multirow{2}{*}{ Location } & \multirow{2}{*}{ Patron-saint } & \multirow{2}{*}{$\begin{array}{l}\text { Archaeol. } \\
\text { continuity }\end{array}$} & \multicolumn{3}{|c|}{ EAST } & \multicolumn{3}{|c|}{ WEST } \\
\hline & & & & Declination & Calendar date & Margin of error & Declination & Calendar date & Margin of error \\
\hline 1 & Arnače & Giles & $\mathrm{P}$ & 2,4000 & 19. Mar/ 10. Sep & 2 days & 2,56797 & 19. Mar/9. Sep & 2 days \\
\hline 2 & Bevče & Nicholas & $\mathrm{P}$ & 15,15788 & 25. Apr / 5. Aug & 0,2254 & $-0,73426$ & 11. Mar/ 18. Sep & $1,2921 / 3$ days \\
\hline 3 & Bistrica ob Sotti & Peter & $P, R$ & 4,17959 & 26. Mar/7. Sep & 1 day & 3,68996 & 24. Mar/ 8. Sep & 1 day \\
\hline 4 & Blečji vrh nad Višnjo goro & Benedict & $P, R$ & 10,21819 & 9 Apr / 20. Aug & 2 days & $-3,78873$ & 3. Mar / 25. Sep & 2 days \\
\hline 5 & Bled, otok & Mary & $P, R, M$ & 11,6333 & 14. Apr / 16. Aug & 1 day & $-2,78117$ & 6. $\operatorname{mar} / 23$. Sep & 1 day \\
\hline 6 & Boršt nad Dragonjo & Roch & $P, R, M$ & 0,11879 & 13. Mar/ 15. Sep & $0,9450 / 2$ days & 0,59564 & 14. Mar/ 14. Sep & 1,0650 \\
\hline 7 & Braslovče & Mary & $R, M$ & 8,81372 & 6. Apr / 25. Aug & $0,7833 / 3$ days & $-0,83053$ & 12. $\operatorname{Mar} / 18 . \mathrm{Sep}$ & $0,7833 / 2$ days \\
\hline 15 & Dobrovjje nad Mozirijem & Urban & M & 6,53219 & 30. Mar / 30. Aug & 5 days & 5,14804 & 26. Mar / 2. Sep & 2 days \\
\hline 19 & Domaniševci & Martin & M & $-2,25553$ & 8. Mar / 22. Sep & 1 day & 2,28726 & 19. $\operatorname{Mar} / 10$. Sep & 2 days \\
\hline 24 & Dravograd & Vitus & $\mathrm{R}$ & 6,08348 & 29. Mar/1. Sep & 3 days & 5,41680 & 27. Mar /2. Sep & 1 day \\
\hline 25 & Drožanje & Martin & $\mathrm{P}$ & 5,02895 & 27. Mar/3. Sep & 2 days & $-4,14190$ & 3. Mar / 26. Sep & 3 days \\
\hline 26 & Frluga & Katherine & $\mathrm{P}$ & 7,68447 & 1. Apr / 26. Aug & 2 days & $-4,48473$ & 1. Mar / 26. Sep & 2 days \\
\hline 31 & Gora pri Krškem & Lawrence & $\mathrm{R}$ & $-1,84907$ & 9. Mar / 21. Sep & 1 day & 1,2833 & 16. Mar/ 12. Sep & 1 day \\
\hline 32 & Gorenja Lepa vas & Primus and Felician & 1 & 2,9333 & 22. Mar/8. Sep & 1 day & $-1,8010$ & 8. Mar / 21. Sep & 1 day \\
\hline 34 & Gorenje Laknice & Judoc & $\mathrm{P}$ & $-1,75047$ & 9. Mar / 21. Sep & 1 day & 8,6500 & 5. Apr / 24. Aug & 3 days \\
\hline 38 & Gorenji Petrovci & Trinity & $\mathrm{P}$ & $-1,21887$ & 10. Mar / 19. Sep & 2 days & 0,6500 & 14. Mar / 14. Sep & 1 day \\
\hline 42 & Iška vas & Michael & $P, R, M$ & 22,95464 & 1. Jun / 27. Jun & 1,3917 & $-0,32174$ & 11. Mar/ 15. Sep & $0,4583 / 2$ days \\
\hline 46 & Jezero pri Trebnjem & Peter & $P, R$ & $-0,03600$ & 14. Mar/ 16. Sep & $0,3338 / 1$ day & 2,90262 & 21. Mar/8. Sep & $0,3338 / 1$ day \\
\hline 48 & Jurklošter & Martin & $P, R, M$ & 16,42200 & 29. Apr /1. Aug & 0,6208 & $-1,06425$ & 10. Mar/ 18. Sep & $1,2875 / 3$ days \\
\hline 49 & Kamnik, Mali grad & Giles & $P, R, M$ & 20,95482 & 18. May / 13. Jul & 1,7913 & $-0,27333$ & 13. Mar/17. Sep & 4,9913/13 days \\
\hline 50 & Koper & Mary & $P, R, M$ & 3,5833 & 22. $\operatorname{mar} / 7$. Sep & 1 day & $-1,33552$ & 11. Mar / 20. Sep & 1 day \\
\hline 62 & Log pri Sevnici & Cross & $P, R$ & 7,89130 & 3. Apr / 27. Aug & $0,4204 / 1$ day & 0,94091 & 16. Mar/13. Sep & 1,4871 \\
\hline 64 & Lopata & Agnes & $P, M$ & 0,62836 & 15. Mar/ 15. Sep & 0,6721 & 2,90767 & 21. Mar/8. Sep & $0,1388 / 1$ day \\
\hline
\end{tabular}

\begin{tabular}{|c|c|c|c|c|c|c|c|c|c|}
\hline 68 & Malo Črnelo & Margareth & $P, R$ & 7,96378 & 3. Apr / 27. Aug & 1 day & $-0,97103$ & 11. Mar / 18. Sep & 2 days \\
\hline 70 & Mošnje & Andrew & $\mathrm{R}, \mathrm{M}$ & $-1,56783$ & 10. Mar/21. Sep & 3 days & 8,2501 & 4. Apr / 26. Aug & 3 days \\
\hline 71 & Mrzla Planina pri Sevnici & Primus and Felician & $\mathrm{R}$ & $-2,60507$ & 7. Mar / 23. Sep & 2 days & 7,1667 & 1. Apr / 28. Aug & 5 days \\
\hline 72 & Muljava & Mary & $P, R, M$ & 6,10756 & 30. Mar/1. Sep & 5 days & $-1,55512$ & 9. $\operatorname{mar} / 20$. Sep & 1 day \\
\hline 73 & Nova cerkev & Leonard & $\mathrm{R}$ & 10,35681 & 10. Apr / 19. Aug & 2 days & -4.9876 & 2. Mar / 26. Sep & 2 days \\
\hline 79 & Paški Kozjak & Hermagoras and Fortunatus & $\mathrm{P}$ & $-1,05258$ & 10. Mar/ 18. Sep & 2 days & 2,34696 & 19. Mar/ 9. Sep & 2 days \\
\hline 82 & Pevno pri Škofji Loki & Ursula & $P, R, M$ & 9,35502 & 7. Apr / 23. Aug & 1 day & $-2,64122$ & 6. $\operatorname{mar} / 22$. Sep & 2 days \\
\hline 85 & Planinca nad Jezerom & Thomas & $P$ & 3,85345 & 24. Mar/6. Sep & 1 day & $-1,41124$ & 10. Mar / 19. Sep & 2 days \\
\hline 90 & Polzela & Margareth & $P, R$ & 4,87706 & 26. $\operatorname{Mar} / 4$. Sep & 2 days & $-1,17986$ & 10. Mar/ 19. Sep & 2 days \\
\hline 91 & Prevole & Cross & P & 1,1001 & 16. Mar/13. Sep & 1 day & 2,62471 & 19. Mar / 9. Sep & 1 day \\
\hline 95 & Ravne na Koroškem & & $\mathrm{R}, \mathrm{M}$ & $-1,24560$ & 10. Mar/ 19. Sep & 2 days & 6,9667 & 31. Mar / 28. Aug & 1 day \\
\hline 96 & Razvanje pri Mariboru & & $P, R$ & $-1,51222$ & 11. Mar/21. Sep & $1,4704 / 3$ days & 8,79926 & 6. Apr / 25. Aug & 1,5904 \\
\hline 104 & Sevnica & & $P, R, M$ & 5,05214 & 25. Mar/1. Sep & 3 days & 12,7501 & 15. Apr / 10. Aug & 3 days \\
\hline 105 & Slančji vrh & Ulrich & $P, R$ & $-4,3667$ & 3. Mar / 27. Sep & 1 day & 4,06246 & 24. Mar/5. Sep & 1 day \\
\hline 106 & Slepšek & Martin & $P, R$ & 3,72018 & 23. $\operatorname{Mar} / 7 . \mathrm{Sep}$ & 2 days & 8,0333 & 3. Apr / 26. Aug & 4 days \\
\hline 108 & Smrečje nad Vrhniko & Ulrich & $P, R$ & 1,7001 & 18. Mar/12. Sep & 3 days & 3,95882 & 23. Mar / 6. Sep & 8 days \\
\hline 109 & Spodnja Besnica & John the Baptist & $\mathrm{P}$ & 4,85617 & 26. Mar/ 3. Sep & $-0,7638 / 2$ days & $-0,76814$ & 11. Mar / 17. Sep & $0,7771 / 2$ days \\
\hline 110 & Spodnje Bitnje & Nicholas & $\mathrm{R}$ & $-1,03514$ & 10. Mar/18. Sep & 2 days & 4,48069 & 24. Mar/4. Sep & 1 day \\
\hline 111 & Spodnje Hoče & George & $\mathrm{R}, \mathrm{M}$ & 1,5167 & 18. Mar/ 13. Sep & 2 days & 2,96408 & 22. Mar/ 9. Sep & 2 days \\
\hline 112 & Spodnje Vitovlje & Peter & $\mathrm{R}, \mathrm{M}$ & 3,2167 & 21. Mar/8. Sep & 1 day & 6,36867 & 29. Mar / 30. Aug & 1 day \\
\hline 113 & Stari trg pri Ložu & George & $\mathrm{P}, \mathrm{RM}$ & 0,6502 & 16. Mar/ 15. Sep & 1 day & 12,8667 & 17. Apr / 13. Aug & 3 days \\
\hline 114 & Stari trg pri Slovenj gradcu & Pancras & $\mathrm{R}, \mathrm{M}$ & 10,27353 & 10. Apr / 20. Aug & 2 days & $-3,45356$ & 4. Mar / 24. Sep & 1 day \\
\hline 115 & Stična & Mary & $P, R$ & $-2,19561$ & 9. Mar / 22. Sep & 3 days & 12,3667 & 16. Apr / 14. Aug & 2 days \\
\hline 117 & Stražǐščce, Kranj & Peter & $P, R$ & 0,28909 & 16. Mar/17. Sep & 1 day & 3,20978 & 23. Mar/9. Sep & 1 day \\
\hline 118 & Stražnji vrh & Nicholas & $P$ & 10,34258 & 10. Apr / 20. Aug & $0,4658 / 2$ days & $-2,05776$ & 8. Mar/21. Sep & $4,5992 / 13$ days \\
\hline
\end{tabular}

Figure 11. The data records for the churches with both calendar and astronomical orientations towards both vernal and autumnal equinoxes on both eastern and western horizons (Figure 8, Figure 9, Figure 10). 


\begin{tabular}{|c|c|c|c|c|c|c|c|c|c|}
\hline 123 & Svete Gore & Martin & $P, R, M$ & 5,39215 & 29. Mar/4. Sep & 4 days & -5.35678 & 1. Mar/1. oct & 3 days \\
\hline 124 & Sv.Tomaž nad Škofjo Loko & Thomas & $P$ & 4,31295 & 25. Mar/5. Sep & $0,8429 / 2$ days & $-0,49011$ & 12. Mar/17. Sep & $0,7763 / 2$ days \\
\hline 125 & Sv. Vid nad Brežicami & Vitus & $P, R, M$ & 4,08433 & 23. Mar/5. Sep & 2 days & $-3,55834$ & 3. Mar / 24. Sep & 2 days \\
\hline 126 & Svibno & Cross & $P$ & $-4,1333$ & 3. Mar/27. Sep & 2 days & 5,41129 & 27. Mar/2. Sep & 2 days \\
\hline 127 & Šempeter v Sav, dolini & Peter & $P, R$ & $-2,21760$ & 9. Mar / 22. Sep & 3 days & 3,81903 & 23. Mar/7. Sep & 1 day \\
\hline 131 & Šentjurij na Dolenjskem & George & $P, R$ & 5,26352 & 27. Mar/ 3. Sep & 2 days & 3,15801 & 21. Mar/ 8. Sep & 1 day \\
\hline 141 & Špitalič & Mary & $P, R, M$ & 4,31017 & 25. Mar/5. Sep & 1 day & 6,30273 & 29. Mar / 30. Aug & 2 days \\
\hline 142 & Štatenberk & Martin & $P, R, M$ & 4,86797 & 26. Mar/4. Sep & $2,6025 / 6$ days & 1,81734 & 18. Mar / 11. Sep & 2,6025 \\
\hline 150 & Trebča vas & Agathius & $\mathrm{R}$ & $-2,23799$ & 8. Mar/22. Sep & 1 day & 5,89166 & 28. Mar/1. Sep & 1 day \\
\hline 151 & Trnovec nad Sevnico & George & $\mathrm{R}$ & 4,51650 & 25. Mar / 4. Sep & 1 day & $-1,61152$ & 8. Mar/ 19. Sep & 2 days \\
\hline 152 & Tržiščce pri Mokronogu & Mary & $P, R, M$ & 22,3502 & 27. May / 3. Jul & 14 days & $-2,51560$ & 6. Mar/22. Sep & 2 days \\
\hline 156 & Velike Brusnice & Holy Family & $P, R$ & -0.7765 & 12. Mar / 18. Sep & $3,1100 / 8$ days & 6,26942 & 29. Mar/31. Aug & $0,4833 / 2$ days \\
\hline 161 & Vinji vrh pri Beli cerkvi & Mary & $P, R, M$ & 4,64936 & 25. Mar/4. Sep & 3 days & $-3,73744$ & 3. Mar/25. Sep & 1 day \\
\hline 170 & Zgornja Draga & Michael & $P, R$ & 6,91118 & 1. Apr / 30. Aug & 2 days & 0,8002 & 16. Mar/ 14. Sep & 1 day \\
\hline 171 & Zgornje Bitnje & Thomas & $P$ & $-0,99223$ & 11. Mar/ 19. Sep & 2 days & 3,89098 & 23. Mar/6. Sep & 2 days \\
\hline 174 & Žiganja vas & Ulrich & $\mathrm{R}$ & 3,51335 & 23. Mar/7. Sep & 6 days & 3,89733 & 23. Mar/6. Sep & 2 days \\
\hline
\end{tabular}

Figure 11. (Continued).

on 13 March (Figure 12). Focusing on the dates that mark the astronomical division of a year (Figure 13), we may be able to extract the more precise timeframe of the calendar jon which Hildebrand and later Trubar based their records, Due to the structure of a solar calendar (the Julian and Gregorian), the $\delta$ of the Sun changes on a yearly basis on the same date. With the intercalations of a day every four years, the individual dates repeat approximately at four-year intervals, with two dates alternating until one of them prevails (Figure 14). This allows a deduction that the dates originated in a calendar for some undetermined year between the beginnings of the thirteenth to the middle of the fourteenth century (Makarovič 1995, 49; Schnurrer 1799, 26; Pintar 1908, 273).

The results confirmed the well-known importance of spring for vernacular communities and revealed the instruments that they used to mark the start of the season. The alignment to the beginning of the agrarian spring, to the Chair of St Peter, was intentionally registered in 19 churches $(11 \%)$, with all marking the festival on their eastern horizon. St_Gregory's festival, the last day of astronomical winter, was registered in the orientation of 22 churches (13\%), almost equally on both horizons. Other dates documented within the vernacular calendar do not have any significant number of churches oriented to them.

\section{Discussion}

The results noted earlier are consistent with the concepts of space and time of past societies, which are viewed as cultural products or artefacts that remain embedded and embodied in physical objects, events, and processes of the past. All human activities were and continue to be performed in space and time; therefore, space and time represent significant factors of divisions and hierarchies in a society. In fact, when anthropologists speak of space and time, they often mean concepts of social space and social time (Iwaniszewski 2015). Anthropological research can be critical in reconstructing ancient lifeways. Anthropological evidence, collected among modern traditional societies, indicates highly context-rich and context-dependent conceptions of time and space (Ruggles 1997, S48; see also Lane [2016]). Historically, people tried to make sense of the passage of time by classifying and categorizing their personal or shared events. Similarly, 
Figure 12.

$$
\text { KOLENDAR. }
$$

Susher, Martius.

$x$ d Albinafcoffa

2 e Simplicia fcoffa

3 D Danoxï,vi Kune Ceffa

$4 \mathrm{~g}$ Bufebia fooffa

5 A Fara Marc.

6 b Fridolina fpouidnika

7 cTomasha Aquinara,

8 d Filemona podrushnika

ge Dominica Appata

o f A lexandraGaya

1 gStyrideffeti Martinikou 1 c Procora feoffa

12 A Gregoriapapesha

13. BNuzh Danglih

14 c Zaharia Papesha

15 d Longina Mart.

16 e Bllara Daciana

$27 \mathrm{f}$ Gere dazhle

$18 \mathrm{~g}$ Brebertassholneria

29 $\mathrm{A}$ Dan xij。 V8. Ioshefa

20 b Gutpertaficolfa

21 cBenedika appata

22 d Perpetue dezhle

23 e Teodorica Mart,

24 f Pigmeniaskoffa

$25 \mathrm{~g}$ Ornanena Marie

26 A Caffola Mart.

27 b V ftanena Criltufeuí, a

28c Prishta Malha

20 d Procia Marc.

30e Amofafcofta

3: f Guida appara
Malicrawn, Apritico

1 g preobernena Magdal.

2 A Teodofie dezhle

3 b Vgafchoffa

4 c Agape Ciconie

$5 \mathrm{~d}$ pan ziling, vzo Irene

6 e Diogena Mart.

7 fCeleftina papesha

$8 \mathrm{~g}$ Diashcora appara

9 A. Marie Bgiptoue?

$10 \mathrm{~b}$ Ezehiela preroka

12 d Ireneinglars.

13 e Bgefippifcoffa

14 f Tiburtia Valeriana

25 g Olimpiada Mart.

$16 \AA$ Aburdafpouidnika

17 b Rudulía fcos

18 c Iubia icofía

19 d Sulpitia Mart:

zoeSymeona Mare

2if. cruilian shoineris

22 Jayzísapesha

27 is Dan xvave

24 bluriassarno

2 s c Marcanuangelifa

26 d Alberta fcoifa

$2 \%$ e Anaclera papg

28 f Vitala Wars.

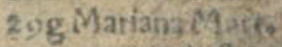

$30 \AA$ Butroplafoso
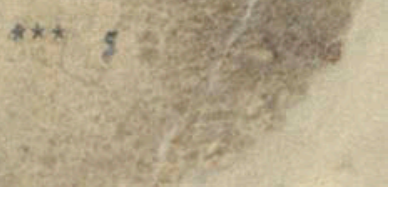

\begin{tabular}{|c|c|c|c|c|}
\hline BEGINNING OF ... & SPRING & SUMMER & AUTUMN & WINTER \\
\hline $\begin{array}{l}\text { AGRARIAN } \\
\text { DIVISION }\end{array}$ & $\begin{array}{l}\text { February } 22^{\text {nd }}- \\
\text { The Chair of St. Peter }\end{array}$ & $\begin{array}{l}\text { May } 25^{\text {th }}- \\
\text { St. Urban }\end{array}$ & $\begin{array}{l}\text { August } 24^{\text {th }}- \\
\text { St. Bartholomew }\end{array}$ & $\begin{array}{l}\text { November } 23^{\text {rd }}- \\
\text { St. Clement }\end{array}$ \\
\hline $\begin{array}{l}\text { ASTRONOMICAL } \\
\text { DIVISON }\end{array}$ & $\begin{array}{c}\text { March } 13^{\text {th }}-\text { a day after } \\
\text { the festival of St. Gregory, } \\
\text { March } 12^{\text {th }}\end{array}$ & $\begin{array}{c}\text { June } 14^{\text {th }}-\text { a day before } \\
\text { the festival of St. Vitus, } \\
\text { June } 15^{\text {th }}\end{array}$ & $\begin{array}{l}\text { September } 15^{\text {th }}-\text { a day after } \\
\text { the Feast of the Exaltation of } \\
\text { the Holy Cross, Sept. } 14^{\text {th }}\end{array}$ & $\begin{array}{l}\text { December } 14^{\text {th }}-\text { a day } \\
\text { after the festival of St. } \\
\text { Lucia, Dec. } 13^{\text {th }}\end{array}$ \\
\hline
\end{tabular}

Figure 13. Liturgical festivals acting as partitions for annual seasons following agrarian and astronomical divisions in the Trubar calendar (AD 1557). 


\begin{tabular}{|c|c|c|c|}
\hline VERNAL EQUiNOx & SUMMER SOLSTICE & AUTUMNAL EQUiNOX & WINTER SOLSTICE \\
\hline $12^{\text {th }}, 13^{\text {th }}$ March & $13^{\text {th }}, 14^{\text {th }}$ June & $14^{\text {th }}, 15^{\text {th }}$ September & $13^{\text {th }}, 14^{\text {th }}$ December \\
\hline
\end{tabular}

Figure 14. In the period around the beginning of the fourteenth century these were the dates, exchanging on a four-year base as per natural festival (source URL: https://www.timeanddate.com/calendar/seasons.html?year= $1300 \& n=736$.$) .$

prosperous places charged landscapes with meaning and gave rise to sacred geographies (Ruggles 1997, 48; McCluskey 2010; Lopez 2015).

An extensive body of literature addresses sacred space and time within religious studies. The works of Dürkheim (2008), van Gennep (2013), Eliade (1959), van der Leeuw (2014) as well as Smith (1987), Bell (1997) and Anttonnen (1996; 2000; 2005) are highly relevant to the present study. The astronomical orientation of churches combines, conveys and communicates sacred time and space in a single cultural or religious object; it delivers a continuous catchment of a singular sanctified moment in a year within a consecrated structure. Considerable preparation and planning had to be mustered into a site for it to capture the divine interplay. A church had to be erected strategically: to register an exact time within a whole year it needed to be built in a specific place, set with a particular layout and in a precise direction while continuously considering the horizon. Although the present text addresses the festivals that are focused around the solstices and equinoxes, the same idea is conveyed in every astronomically oriented sacred structure, without regard to a geographical area and chronological period (Ruggles 2005 ; Magli 2016; cf. Lundquist $[2016,50,51$, fn. 7]).

Lundquist's $(1983,2016)$ comparative study of ancient Near Eastern temples states a few theorems attesting that the temple and its rituals are linked to cosmogony and were seen as a copy or counterpart of a heavenly model (Lundquist 2016, 53; Morales 2014, 6). Judaism took over the ancient concept of a temple as a consecrated image of the cosmos and Christianity inherited and embedded it in its own temple, a church (Eliade 1974; Clements 2016; de Blaauw 2012, 15; Morales 2014, 1-10). Although somewhat out-dated within religious studies, Eliade's view is nevertheless applicable: 'The four parts of the interior of the church symbolize the four cardinal directions. The interior of the church is the universe. The altar is the paradise, which lay in the East' $(1959,61)$.

One of the three basic requirements of a church from Constantine's time (AD 306-337) was alignment on a 'cosmic axis' (de Blaauw 2012, 2016, 557). At some point between Early Christianity and the medieval period, the more exact orientation of churches was adopted. When and why this happened remains poorly understood. However, the topic has been well addressed in the lberian Peninsula. An exhaustive study of Iberian pre-Romanesque churches showed that the vast majority of churches from the late fourth to eleventh centuries was orientated toward sunrise on 25 March. i.e. the Roman vernal equinox and Christian liturgical festival of St_Mary's Annunciation (GonzálezGarcía and Belmonte 2015). In addition, the study of a sixth-century church in the hill fort of Tonovcov grad in western Slovenia showed that a more detailed and possibly politically directed orientation - not simply towards east - was incorporated in churches already in the first half of the sixth century AD in that region as well (Čaval and Šprajc 2011).

Focusing here only on the timeframe of equinoxes and solstices, the study of Romanesque churches in Slovenia exhibited that both solstices provided meaningful moments in the agricultural and ritual year. The apparent annual path of the Sun on the horizon became a significant part 
of the symbolic world of many cultures and religions. Whether in prehistoric, Roman pagan or Christian worlds, the two solstices became a principal moment in the calendar year (Ruggles 2005). The first ecumenical council determined 24 June and 25 December as the official dates for summer and winter solstice; the two became major Christian festivals commemorating the births of St John the Baptist and Jesus Christ respectively (McCluskey 2007; cf. Hijmans [2003]). With the lengthy observational timespan around the solstices - about two weeks - there is a possibility for a church to be oriented instead to these other days: the festival of St Peter and Paul on 29 June (Western church) or 28 December (Eastern church), St Thomas on 3 July jer 21 December, St_Stephen on 26 December, St Vitus on 15 June, and to St James the Greater, initially on 27 December. However, for a church to be interpreted as such, there would have to be very strong contextual support.

Much more complicated is the situation with the equinox. The pronounced variety of the dates commemorating both equinoxes spreads the timeframe only to a week (Figure 8, Figure 9). The equinoctial east was a widespread orientation of medieval churches in Slovenia. Actually, considering all possible orientations that can be interpreted as equinoctial - declinational and the calendar dates associated with the equinoxes - the final number rises to almost $40 \%$ of all medieval churches studied. This is not an isolated case, as a very similar situation can be observed in the Iberian Peninsula (González-García and Belmonte 2015). The results of both studies corroborate the works of the twelfth and thirteenth century's authors who advocated for the alignment of churches 'not just any east but specifically the equinoctial east' (vide supra). One intriguing outcome is that out of 15 churches that are oriented towards the point of sunrise on the day of true or astronomical equinox $\left(\delta=0^{\circ} \pm 0.2\right)$, 10 register this orientation on the less significant western horizon (Figure 11). Some of those structures were planned and built in such a way that they disclosed the specific moment in both the tropical year and liturgical calendar, and on both eastern and western horizons (Figure 10). Considering the high possibility of a precise observation, is it by chance that some churches mark a natural or/and calendar festival on both horizons? This is highly unlikely; in archaeoastronomy the horizon defines the orientation of a structure. In a mountainous country such as Slovenia, if churches were planned to be oriented according to the Sun - either a calendar date or the Sun's astronomical position - the right direction had to be determined by observation. Additionally, Bede tells us about the known nonconformity of the natural year and Julian calendar in the eighth century (Nothaft 2011, 101); thus, the difference between both only grew larger by the Romanesque period. The church designers had to incorporate this difference in the church as well. Therefore, registering true and calendar equinox in a single sacred building can be seen as praise of a specific and significant date. It is an endeavour to register a liturgically important festival on the appropriate, eastern side, and, so as not to come into conflict with clerical authority, to mark a natural festival on the ecclesiastically less important, western side of a church. If those churches were built on the exact pre-existent sacred structure, this indicates that a church discloses the pagan sacred orientation on one side and Christian sacred orientation on its other. The Mozarabic church San Juan de la Peña, in Huesca province, Spain, is a similar example of such practice, although it registers both solstices (González-García and Belmonte 2015). Bearing all this in mind and removing the religious implication, it is reasonable to suggest that some medieval churches were themselves a type of gnomon or sundial. Concurrently, they would stay true to the astronomical cycles of the Sun throughout time and commemorate the contemporary calendar, which was approved by the highest ecclesiastical authority, yet misaligned with the celestial cycles. Therefore, their design could be described as scientific. 
The vernacular calendar was derived from the agricultural needs of a society in the region. Hence, it is understandable why only the spring dates for both the vernacular and astronomical division of a year were registered in the church orientations. The still-performed local tradition of candles floating on water (a river, creek, lake) on St Gregory's Day is linked to the pre-Christian celebration of a new year. This custom, known from other parts of Europe as well, is always related to the spring equinox. Furthermore, the traditional Slavic New Year was the vernal equinox, though usually celebrated in the first part of March (Conrad 1985; Knific 2017, 75). Although the calendar changed, the festival of St Gregory was not transferred 10 days forward, yet the special significance of this date remained. Therefore, today St Gregory is celebrated as the vernacular beginning of spring in Slovenia, the day when 'the birds get married',

\section{Conclusion}

This paper has examined the extraordinary interplay between natural and calendar festivals conveyed in medieval church building, which simultaneously aligned with regional cultures of timekeeping. Ruggles (1997) and González-García and Belmonte (2006), respectively, note similar interactions for prehistoric and Roman periods. Timekeeping was an essential aspect of past cultures and evidence of a developed society. Here, the focus has been on the medieval period in Slovenia, encompassing a variety of vernacular, ethnological, anthropological and historical aspects, those developed and initially used by people, purely within their economic and religious dominion respectively. Only later was religious - unnatural - time added to the vernacular calendar and the two merged (Makarovič 1995, 45).

Given that this research incorporates evidence representing some $80 \%$ of all Romanesque churches in Slovenia, it is clear that location and alignment were carefully selected, with each church having contingent reasons for its orientation. The most frequently registered dates to which churches are aligned correspond to several calendar feasts, which were mostly already celebrated jefore the eighth century. For the natural festivals, the plethora of equinox-related calendar dates and orientations display various concepts of the equinox, as well as non-universality in timekeeping, and exhibits the reasons behind the construction of various calendars. It also demonstrates the profound relationship of the equinox period to the beginning of spring in the northern hemisphere regarding both religious ideologies and economic factors. A considerable number of churches also register the unexpected combination of natural and calendar festivals that commemorate an astronomical moment in a tropical year. These churches exemplify eternal calendars (i.e. astronomical cycles in real time) as well as official time reckoning, i.e. Julian calendar.

In conclusion, despite the universal sacredness of, and enduring fascination with, celestial bodies, the specific significant moments in their cycles and the universal idea of east-west orientation can be refined through understanding local economic as well as religious practice. The correct location for religious rituals comes from the 'irruption of the divine' (Eliade 1959) and also from the sense of the hierarchical differentiation of space, which implies its social origin (Durkheim 2008, 11). The same applies to time, an abstract and impersonal frame that surrounds all humanity. Time is measured by a calendar, which expresses the rhythm of the collective social and sacred activities (rites, feasts, public ceremonies) and assures their regularity (Dürkheim 2008, 10-13). Astronomically oriented churches, an exclusive combination of time and location, are another form of timekeeping, an amalgamation of calendars, impervious to non-alignment of celestial cycles and the human need to measure and regulate the world around us. 


\section{Acknowledgements}

I would like to express my sincere gratitude to colleagues at the Institute of Spatial and Anthropological Studies in Slovenia, in particular to Ivan Šprajc, Krištof Oštir, Klemen Zakšek and_Peter Pehani, and at Stanford University to Claudia Engel, for their support and help with the project, data processing and visualizations. I would like to thank Krish Seetah, Kelda Jamison and Phil Hubbard for their help with the text, two anonymous reviewers for their helpful comments and the editor of this issue, Naomi Sykes.

\section{Disclosure statement}

The author reported no potential conflict of interest.

\section{Notes on contributor}

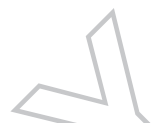

Saša Čaval is a lecturer at the Department of Anthropology at Stanford University, U.S.A. She was recently awarded the Marie Skłodowska Curie Fellowship at the Department of Archaeology, University of Reading. Her research focuses on the archaeology of religion with regional foci spanning south-eastern Europe and the Indian Ocean. She is particularly interested in the application of astronomy as a tool to understand the expression of beliefs within past societies and in spiritual and social relationships of medieval communities to their landscape in south-eastern Europe. Within historical archaeology she studies the construction of identity, using religion and religious expression by descendent communities on formerly colonized island enclaves, with Mauritius as a principle case study.

\section{ORCID}

Saša Čaval (i) http://orcid.org/0000-0002-9337-3951

\section{References}

Andrén, A. 2013. "The Significance of Places: The Christianization of Scandinavia from a Spatial Point of View." World Archaeology 45 (1): 27-45. doi:10,1080/00438243.2013.758939.

Anttonen, V. 2005. "Space, Body, and the Notion of Boundary: A Category-Theoretical Approach to Religion." Temenos-Nordic Journal of Comparative Religion 41 (2): 185-201.

Anttonnen, V. 1996. "Rethinking the Sacred: The Notions of 'Human Body' and 'Territory' in Conceptualizing Religion." In The Sacred and Its Scholars. Comparative Methodologies for the Study of Primary Religious Data, edited by T. A. Idinopulos and E. A. Yonan, 36-64. Leiden: Brill.

Anttonnen, V. 2000. "Sacred." In Guide to the Study of Religion, edited by R. T. McCutcheon and W. Braun, 271282. London: Cassell.

Aveni, A. F. 2001. Skywatchers: A Revised and Updated Version of Skywatchers of Ancient Mexico. Austin: University of Texas Press.

Balboni, D. 1967. La cattedra di San Pietro: Note storico-liturgiche sul'origine della festa "Natale Petri de Cathedra" e sul culto alla "Cathedra Petri." Vatican City: Tipografia Poliglotta Vaticana.

Barnish, S. J. 2001. "Religio in stagno: Nature, Divinity, and the Christianization of the Countryside in Late Antique Italy." Journal of Early Christian Studies 9 (3): 387-402. doi:10.1353/earl.2001.0037.

Bede. 1907. Bede's Ecclesiastical History of England. A Revised Translation with Introduction, Life, and notes by A. M. Sellar. London: George Bell and Sons. https://www.gutenberg.org/files/38326/38326-h/38326-h. html\#toc71

Bell, C. 1997. Ritual: Perspectives and Dimensions. Oxford: Oxford University Press.

Boyd, W. K. 1905. The Ecclesiastical Edicts of the Theodosian Code (No. 63). Studies in History, Economics and Public Law. Vol. 24/2. New York: Columbia University Press, the Macmillan Company, agents. 
Bradley, R. 2002. The Past in Prehistoric Societies. London: Routledge.

Čaval, S., and I. Šprajc. 2011. "Astronomical Orientation of Churches at Tonovcov grad." In Late Antique Fortified Settlement Tonovcov grad near Kobarid. Settlement Remains and Interpretation, edited by S. Ciglenečki, Z. Modrijan, and T. Milavec, Opera Instituti Archaeologici Sloveniae 23, 247-255. Ljubljana: Založba ZRC.

Čaval, S., K. Zakšek, and I. Šprajc. forthcoming

Clements, R. E. 2016. God and Temple: The Idea of the Divine Presence in Ancient Israel. Eugene: Wipf and Stock Publishers.

Coleman, C. B. 1914. Constantine the Great and Christianity: Three Phases: The Historial, the Legendary, and the Spurious, Issues 146-147. Issue 146 of Columbia Studies in the Social Sciences. New York: Columbia University Press.

Conrad, J. L. 1985. "Ritual and Customs along the Kolpa (Bela krajina)." Slovene Studies 7 (1-2): 23-33.

de Blaauw, S. 2012. "In View of the Light: A Hidden Principle in the Orientation of Early Christian Church Building." In Medieval Art. The Routes of liturgical Space, edited by P. Piva, Chap. 1, 15-45. London: Folio Society.

de Blaauw, S. 2014. "Liturgical Features of Roman Churches: Manifestations of the Church of Rome?" In Chiese locali e chiese regionali nell'alto Medioevo. Settimane di Studio del Centro Italiano di Studi, Vol. LXI, 321-338. Spoleto: Fondazione Centro Italiano di studi sull'alto Medioevo.

de Blaauw, S. 2016. "A Classic Question: The Origins of the Church Basilica and Liturgy." In Costantino e i costantinidi. L'innovazione costantiniana, le sue radici e i suoi sviluppi. Acta XVI Congressus Internationalis Archaeologiae Christianae. Romae (22-28.9.2013), edited byO. Brandt, V. Fiocchi Nicolai, and G. Castiglia. Studi di antichità cristiana 66. 2 vols. Vol. I, 553-562. Città del Vaticano.

Dürkheim, E. 2008. The Elementary Forms of the Religious Life. Translated by J. W. Swain. Mineola: Dover Publications.

Eastwood, B. 2007. Ordering the Heavens: Roman Astronomy and Cosmology in the Carolingian Renaissance. Leiden: Brill.

Eliade, M. 1959. The Sacred and the Profane: The Nature of Religion. Harvest Book 144. New York: Houghton Mifflin Harcourt.

Eliade, M. 1974. The Myth of the Eternal Return: Cosmos and History. Princeton: Princeton University Press.

Equinox and Solstice 1000 B.C. to A.D. 2999. http://www.beda.cz/ jirkaj/seasons/

Fernie, E. 2014. Romanesque Architecture: The First Style of the European Age. New Haven: Yale University Press. Firneis, M. G., and C. Köberl. 1988. "Further Studies on the Astronomical Orientation of Medieval Churches in Austria." In World Archaeoastronomy: Selected Papers from the 2nd Oxford International Conference on Archaeoastronomy, held at Merida, Yucatan, Mexico, 13-17 January 1986, edited by A. F. Aveni, Chap. 33, 430-435. Cambridge: Cambridge University Press.

Fogelin, L. 2007. "The Archaeology of Religious Ritual." Annual Review of Anthropology 36 (1): 55-57. doi:10.1146/annurev.anthro.36.081406.094425.

Gangui, A., A. Garcia, M. A. P. Betancort, and J. A. Belmonte. 2016. "On the Orientation of the Historic Churches of Lanzarote: When Human Necessity Dominates over Canonical Prescriptions." In The Materiality of the Sky. Proceedings of the 22nd Annual SEAC Conference 2014, edited by F. Silva, K. Malville, T. Lomsdalen, and F. Ventura, 125-134. Lampeter: Sophia Centre Press.

Goldstein, B. R. 1972. "Theory and Observation in Medieval Astronomy." Isis 63 (1): 39-47. doi:10.1086/350839.

González-García, A. C., and J. A. Belmonte. 2006. "Which Equinox?" Archaeoastronomy 20: 97-107.

González-García, A. C., and J. A. Belmonte. 2015. "The Orientation of Pre-Romanesque Churches in the Iberian Peninsula." Nexus Network Journal 17 (2): 353-377. doi:10.1007/s00004-014-0231-7.

Gordon, B. L. 1971. "Sacred Directions, Orientation, and the Top of the Map." History of Religions 10: 211-227. doi:10.1086/462630.

Heilbron, J. L. 2001. The Sun in the Church: Cathedrals as Solar Observatories. Cambridge, MA: Harvard 565 University Press.

Helms, M. W. 2004. "Before the Dawn. Monks and the Night in Late Antiquity and Early Medieval Europe." Anthropos 99 (1): 177-191.

Hickman, H. L. 1992. The New Handbook of the Christian Year: Based on the Revised Common Lectionary. Nashville, TN: Abingdon Press. 
Hijmans, S. 2003. "Sol Invictus, the Winter Solstice, and the Origins of Christmas." Mouseion: Journal of the Classical Association of Canada 3 (3): 377-398.

Höfler, J. 2016. O prvih cerkvah in župnijah na Slovenskem: K razvoju cerkvene teritorialne organizacije slovenskih dežel v srednjem veku. [About first churches and parishes in Slovenia: The development of ecclesiastical territorial organisation of Slovene land in the Middle Ages]. Ljubljana: Viharnik.

Hutton, R. 2001. The Stations of the Sun: A History of the Ritual Year in Britain. Oxford: Oxford University Press. Incerti, M. 2013. "Astronomical Knowledge in the Sacred Architecture of the Middle Ages in Italy." Nexus Network Journal 15 (3): 503-526. doi:10.1007/s00004-013-0167-3.

Insoll, T., ed. 2011. Oxford Handbook of the Archaeology of Ritual and Religion. Oxford: Oxford University Press. Iwaniszewski, S. 2015. "Concepts of Space, Time, and the Cosmos." In Handbook of Archaeoastronomy and Ethnoastronomy, edited by C. Ruggles, 3-14. New York: Springer. doi:10.1007/978-1-4614-6141-8_2.

Knific, B. 2017. Gregorjevo: Ko gre luč v vodo in se prične pomlad. [St Gregory's day: When the light is put in the water and the spring starts]. Tržič: Tržiški muzej.

Kocik, T. M. 2003. The Reform of the Reform? A Liturgical Debate: Reform or Return. San Francisco: Ignatius Press. Landsberger, F. 1957. "The Sacred Direction in Synagogue and Church." Hebrew Union College Annual 28: 181203.

Lane, P., ed. 2016. "Ethnoarchaeology." Debates. World Archaeology 48: 5.

Lawrence, C. H. 2015. Medieval Monasticism: Forms of Religious Life in Western Europe in the Middle Ages. London: Routledge.

López, A. M. 2015. "Interactions Between 'Indigenous' and 'Colonial' Astronomies: Adaptation of Indigenous Astronomies in the Modern World." In Handbook of Archaeoastronomy and Ethnoastronomy, edited by C. Ruggles, 197-212. New York: Springer.

Lundquist, J. M. 1983. "What Is a Temple? A Preliminary Typology." In The Quest for the Kingdom of God: Studies in Honor of George E. Mendenhall, edited by H. B. Huffman, F. A. Spina, and A. R. W. Green, 205-219. Winona Lake: Eisenbrauns.

Lundquist, J. M. 2016 (1984). "The Common Temple/deology of the ancient Near East." In Cult and Cosmos: Tilting toward a Temple-Centered Theology, edited by M. L. Morales, Biblical Tools and Studies 18, 49-67. Leuven: Peeters.

Magli, G. 2016. Archaeoastronomy: Introduction to the Science of Stars and Stones. Cham: Springer.

Makarovič, G. 1995. Slovenci in čas: Odnos do časa kot okvir in sestavina vsakdanjega življenja. [Slovenes and Time: Attitude to Time as a Frame and Component of Everyday Life]. Knjižna zbirka Krt 94. Ljubljana: Krtina.

Makarovič, G. 2006. "Pričevanja o svetniških zavetništvih v Trubarjevem katekizmu iz leta 1575" [Testimonies of saints' consecrations in Trubar's Catechism from 1575]. Etnolog 16 (1): 159-195.

McCluskey, S. C. 1982. "Historical Archaeoastronomy: The Hopi Example." In Archaeoastronomy in the New World: American Primitive Astronomy, Proceedings of a Conference held September, 1981 at Oxford University, edited by A. F. Aveni, Chap. 2, 31-57. Cambridge: Cambridge University Press.

McCluskey, S. C. 1998. Astronomies and Cultures in Early Medieval Europe. Cambridge: Cambridge University Press.

McCluskey, S. C. 2004. Astronomy, Time, and Churches in the Early Middle Ages." In Villard's Legacy: Studies in Medieval Technology, Science and Art in Memory of Jean Gimpel, Vista Studies in the History of Medieval Science, edited by M. T. Zenner, Technology and Art 2, 197-210. Aldershot: Ashgate Publishing.

McCluskey, S. C. 2007. Calendrical Cycles, the Eighth Day of the World, and the Orientation of English Churches." In Skywatching in the Ancient World: New Perspectives in Cultural Astronomy, edited by C. Ruggles and G. Urton, Chap. 10, 331-353. Boulder: University Press of Colorado.

McCluskey, S. C. 2010. "Traditional Astronomical Concepts: Linking Space, Time, and Culture." 615 Archaeoastronomy 23: 9-18.

McCluskey, S. C. 2015. "Orientation of Christian Churches." In Handbook of Archaeoastronomy and Ethnoastronomy, edited by S. C. Ruggles, Vol. 3, Part X, Chap. 154, 1703-1710. New York: Springer.

McCormick, M. 2011. Charlemagne's Survey of the Holy Land: Wealth, Personnel, and Buildings of a Mediterranean Church Between Antiquity and the Middle Ages: With a Critical Edition and Translation of the Original Text. Dumbarton Oaks Research Library and Collection.

Mommsen, T. 1859. Die Römische Chronologie bis auf Caesar. Berlin: Weidmannsche Buchhandlung.

Morales, M. L., ed. 2014. Cult and Cosmos: Tilting Toward a Temple-Centered Theology. Biblical Tools and Studies 18. Leuven: Peeters. 
Murphy, P. L., ed. 1960. The New Rubrics of the Roman Breviary and Missal: Translation and Commentary. Sydney: Catholic Press Newspaper.

NASA. Vernal Equinox. Accessed 12 November 2017.https://ssd.jpl.nasa.gov/?glossary\&term=verneq

Newton, R. R. 1972. Medieval Chronicles and the Rotation of the Earth. Baltimore: Johns Hopkins University Press.

Nothaft, C. P. E. 2011. Dating the Passion: The Life of Jesus and the Emergence of Scientific Chronology (2001600). Leiden: Brill.

Nothaft, C. P. E. 2018. Scandalous Error: Calendar Reform and Calendrical Astronomy in Medieval Europe. Oxford: Oxford University Press.

Penprase, B. E. 2017. The Power of Stars. Cham: Springer.

Pintar, L. 1908. "Trubarjev koledar." In Turbarjev zbornik, Zbornik Matice Slovenske, edited by F. Ilešič, Vol. 10, 270-274. Ljubljana: D. Hribar.

Podossinov, A. V. 1991. "Himmelsrichtung kultische." In Reallexikon für Antike und Christentum: Sachwörterbuch zur Auseinandersetzung des Christentums mit der antiken Welt, edited by T. Klauser, Vol. XV, 233-286. Stuttgart: Hiersemann.

Ratzinger, J. 1986. The Feast of Faith: Approaches to a Theology of the Liturgy. San Francisco: Ignatius Press.

Ratzinger, J. 2014. The Spirit of the Liturgy. Translated by J. Saward. San Francisco: Ignatius Press.

Renfrew, C. 1985. The Archaeology of Cult: The Sanctuary at Phylakopi. London: British School of Archaeology at Athens/Thames and Hudson.

Rowland, I. D., and T. N. Howe, eds. 2001. Vitruvius: "Ten Books on Architecture." Cambridge: Cambridge University Press.

Ruggles, C. L. 1997. "Whose Equinox?" Journal for the History of Astronomy 28 (22): S44-S50. doi:10.1177/ 002182869702802205.

Ruggles, C. L. 1999. Astronomy in Prehistoric Britain and Ireland. New Haven: Yale University Press.

Ruggles, C. L. 2005. Ancient Astronomy: An Encyclopaedia of Cosmologies and Myth. Santa Barbara: Abc-Clio.

Šašel Kos, M. 2010. "Adsalluta and Magna Mater: Is There a Link?" In Celtic Religion Across Space and Time: Fontes epigraphici religionvm celticarvmantiqvarvm, edited by J. A. Arenas-Esteban, 242-257. Consejería de Educación y Cultura. Molina de Aragón: Centrode Estudios de Molina y Alto Tajo; Toledo: Junta de Comunidades de Castilla-LaMancha, Servicio del Libro, Exposiciones y Audiovisuales.

Schaefer, B. E. 1993. "Astronomy and the Limits of Vision." Vistas in Astronomy 36: 311-361. doi:10.1016/00836656(93)90113-X.

Schauber, V., and M. Schindler. 1995. Svetniki in godovni zavetniki za vsak dan $v$ letu. [Heilige und Namenspatrone im Jahreslauf] [Saints and patron saints in the course of the year]. Ljubljana: Mladinska knjiga.

Schnurrer, C. F. 1799. Slavischer Bücherdruck in Württemberg im 16. Jahrhundert. Tübingen.

Smith, I. 1996. Vernal Equinox. Date and Time of the Spring Equinox 1452-1811. http://www.newscot land1398.net/equinox/vern 1452.html

Smith, J. 1987. To Take Place: Toward Theory in Ritual. Chicago: University of Chicago Press.

Smolik, M., ed. 2000a. Leto svetnikov II. April - Junij. [A year of saints, Vol. II., April-June]. 2nd ed. Celje: Mohorjeva Založba.

Smolik, M., ed. 2000b. Leto svetnikov III. Julij - September. [A year of saints, Vol. III., July-September]. 2nd ed. Celje: Mohorjeva Založba.

Takács, S. A. 1996. "Magna Deum Mater Idaea, Cybele, and Catullus' Attis." In Cybele, Attis, and Related Cults. Essays in Memory of M. J. Vermaseren, edited by E. N. Lane, 367-386. Leiden: Brill.

Taylor, J. G. 1993. Yahweh and the Sun: Biblical and Archaeological Evidence for Sun Worship in Ancient Israel. A\&C Black.

Thijm, J. A. A. 1858. De Heilige Linie. Proeve over de oostwaardsche richting van kerk en autaar als hoofdbeginsel der kerkelijke bouwkunst. Amsterdam: $\mathrm{CL}$ van Langenhuysen.

Tierney, J. 1911. "New Year's Day." In The Catholic Encyclopedia. New York: Robert Appleton Company. http:// www.newadvent.org/cathen/11019a.htm 1752009.

Trubar, P. 1581/1582. Ta celi noui Testament nashiga Gospudi inu Isuelizharie lesusa Christusa, na dua maihina deilla resdilen, vtim ie is tiga stariga Testamenta dopolnene, suma inu praua islaga, druguzh pregledan inu $v$ kupen drukan, skusi Primosa Truberia Crainza Rastzhizheria. Tübingen: Georg Gruppenbach. URN:NBN:SI: DOC-P23ZYWWR from http://www.dlib.si 
Trubar, P. 1986. Ta slovenski kolendar kir vselei terpi. Facsimile. Ljubljana: Delo, Papirnica Vevče.

Turner, V. 1979. "Frame, Flow and Reflection: Ritual and Drama as Public Liminality." Japanese Journal of 680 Religious Studies 6 (4): 465-499. doi:10.18874/jjrs.

van der Leeuw, G. 2014. Religion in Essence and Manifestation. Princeton: Princeton University Press.

van Gennep, A. 2013. The Rites of Passage. Library Editions, Anthropology and Ethnography. London: Routledge. Vogel, C., M. Nédoncelle, B. Botte, L. De Bruyne, A. Grabar, R. Marichal, C. Mohrmann, and C. Vogel. 1962. "Sol æquinoctialis. Problèmes et technique de l'orientation dans le culte Chrétien." Revue des Sciences Religieuses 36 (3): 175-211. doi:10.3406/rscir.1962.2332.

Xiaojian, J. 2010. "Inquiry into and Analysis of Relation in Yangli of Tanwen and Sun Worship in Ancestors of South Chu." Lanzhou Academic Journal 11: 44.

Zadnikar, M. 1982. Romanika v Sloveniji. Tipologija in morfologija sakralne arhitekture. [Romanesque period in Slovenia. Typology and morphology of the sacral architecture]. Ljubljana: DZS.

Zadnikar, M. 2001. Romanske cerkve v Sloveniji. [The Romanesque churches in Slovenia]. Ljubljana: Družina. Zeilik, M. 1985. "The Ethnoastronomy of the Historic Pueblos, 1: Calendrical sun watching." Journal for the History of Astronomy. Archaeoastronomy Supplement 16 (8): S1-S24. 